\title{
$\mathrm{Nd}-\mathrm{Fe}-\mathrm{Cu} 3$ 元系状態図の熱力学的解析
}

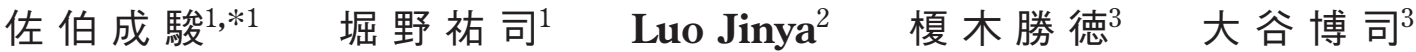

\author{
1東北大学大学院工学研究科知能デバイス材料学専攻 \\ 2九州工業大学大学院工学府 \\ 3 東北大学多元物質科学研究所
}

J. Japan Inst. Met. Mater. Vol. 81, No. 1 (2017), pp. 32-42 Special Issue on Microstructure and Local Magnetism Near Grain Boundaries of Nd-Fe-B Permanent Magnets and Their Impacts on Coercivity (C) 2016 The Japan Institute of Metals and Materials

\section{Thermodynamic Analysis of Phase Equilibria in the Nd-Fe-Cu Ternary System}

\author{
Michitoshi Saeki ${ }^{1, * 1}$, Yuji Horino ${ }^{1}$, Luo Jinya ${ }^{2}$, Masanori Enoki ${ }^{3}$ and Hiroshi Ohtani ${ }^{3}$ \\ ${ }^{1}$ Department of Material Science, Graduate School of Engineering, Tohoku University, Sendai 980-8579 \\ ${ }^{2}$ Graduate School of Engineering, Kyushu Institute of Technology, Kitakyushu 804-8550 \\ ${ }^{3}$ Institute of Multidisciplinary Research for Advanced Materials, Tohoku University, Sendai 980-8577
}

A thermodynamic assessment of the Nd-Fe-Cu system was attempted using the CALPHAD method, to clarify an effect of $\mathrm{Cu}$ addition to the permanent magnets based on $\mathrm{Nd}_{2} \mathrm{Fe}_{14} \mathrm{~B}$ phase. The regular solution model was applied to liquid phase and solid solutions. Intermediate compounds were described as stoichiometric phases. The formation enthalpy of $\delta\left(\mathrm{Nd}_{6} \mathrm{Fe}_{13} \mathrm{Cu}\right)$ phase was evaluated using the first-principles calculation. The result was introduced to the optimization process with some experimental phase boundary data. In the calculated liquidus projection of the ternary system, it is characteristic that the two-phase separation of the liquid phase exists between Fe-rich and $(\mathrm{Nd}, \mathrm{Cu})$-rich regions. The ternary eutectic reaction $\mathrm{E}_{1}:(\mathrm{L}) \Leftrightarrow \beta \mathrm{NdCu}+(\alpha \mathrm{Nd})+\delta$ occurs in the Nd-rich region and the reaction temperature is estimated about $508.6^{\circ} \mathrm{C}$. [doi:10.2320/jinstmet.JA201605]

(Received July 4, 2016; Accepted August 18, 2016; Published December 25, 2016)

Keywords: phase diagram, CALPHAD (calculation of phase diagrams) method, thermodynamic analysis, neodymium-iron-boron permanent magnets, grain boundary

\section{1. 緒言}

1982年に開発された $\mathrm{Nd}_{2} \mathrm{Fe}_{14} \mathrm{~B}$ 相を主相とするネオジム磁 石 ${ }^{1)}$ は, 優れた磁気特性を有しているため, ハードディスク ドライブなどの電子機器や, 電気自動車など幅広い分野で実 用に供されている。その一方で, 駆動用モータとしての利用

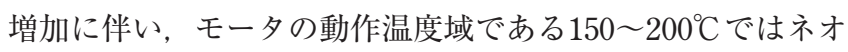
ジム磁石の保磁力が低下する問題が顕在化した. そのため特 に高温度域における保磁力の改善は, ネオジム磁石の実用化 における重要な課題の一つである。 そのような状況を背景と して, 近年 $\mathrm{Nd}-\mathrm{Cu}$ 共晶合金を利用した保磁力改善の手法が 提案された ${ }^{2)}$. この手法では水素化 - 不均化 - 脱水素 - 再融 合法(以下 HDDR 法とする) ${ }^{3)}$ によって作製された $\mathrm{Nd}_{2} \mathrm{Fe}_{14} \mathrm{~B}$ 相の磁粉に, $\mathrm{Nd}-\mathrm{Cu}$ 共晶合金を粒界に沿って浸透させること で高い保磁力の発現を実現している. 従って結晶粒界におけ る $\mathrm{Cu}$ の挙動の理解がネオジム磁石の高保磁力化の基礎的知 見として重要であるが, $\mathrm{Nd}_{2} \mathrm{Fe}_{14} \mathrm{~B}$ 結晶粒界における $\mathrm{Cu}$ の役 割を熱力学的に議論した報告はない.

そこで本研究では，ネオジム磁石を構成する $\mathrm{Nd}-\mathrm{Fe}-\mathrm{Cu} 3$ 元系の状態図を熱力学的に解析し, その結果を用いてネオジ

\footnotetext{
*1東北大学大学院生 (Graduate Student, Tohoku University)
}

ム磁石の粒界における $\mathrm{Cu}$ の挙動を調べた.

\section{2. 解 析 方 法}

$\mathrm{Nd}-\mathrm{Fe}-\mathrm{Cu} 3$ 元系の実験状態図によれば，空間群P Pnmaの 構造を有する $\alpha \mathrm{NdCu}$ 相の $\mathrm{Cu}$ サイトに $\mathrm{Fe}$ が置換型固溶する ことが明らかにされているが4), この 3 元化合物の熱力学的 物性に関する実験報告はない. そこで本章では，はじめに $\alpha \mathrm{Nd}(\mathrm{Fe}, \mathrm{Cu})$ 相の生成自由エネルギーを電子論的に計算する 手順を説明する.ささにこの 3 元系の熱力学的解析に必要な 各相の自由エネルギーモデルについて説明する。

2.1 クラスター展開・変分法による $\alpha \mathrm{Nd}(\mathrm{Fe}, \mathrm{Cu})$ 相の生成 自由エネルギーの計算

$\alpha \mathrm{NdCu}$ 相へ $\mathrm{Fe}$ が置換型固溶した $\alpha \mathrm{Nd}(\mathrm{Fe}, \mathrm{Cu})$ 相の生成自 由エネルギーをクラスター展開・変分法 (Cluster ExpansionCluster Variation Method: 以下 CE-CVM とする ${ }^{5,6)} に よ り$ 計 算した. クラスター展開・変分法は, 個々のクラスターのエ ネルギーであるクラスター有効相互作用 (Effective Cluster Interaction: 以下 ECI とする) と, その配置のエントロピーよ り自由エネルギーを計算する手法であり, その詳細は参考文 献7)に記述したのでここでは紙面の都合上割愛する.

Fig. 1 に $\alpha \mathrm{Nd}(\mathrm{Fe}, \mathrm{Cu})$ の結晶構造を示した. 本研究では黒 


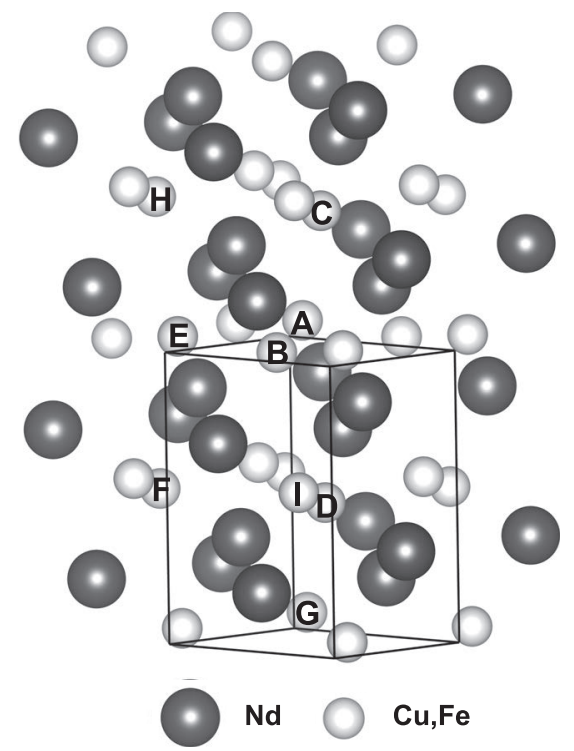

Fig. 1 Schematic illustration of $\alpha \mathrm{Nd}(\mathrm{Fe}, \mathrm{Cu})$ structures. The alphabet put on vertices denotes atomic sites given in Table 1 .

Table 1 Values of ECI for clusters. The alphabet in the third column corresponds to those put on the vertices in Fig. 1.

\begin{tabular}{cccr}
\hline $\mathrm{N}$ & Type & Site & ECI $(\mathrm{meV} /$ site $)$ \\
\hline 1 & null & & 0.146919389 \\
2 & point & A & 89.7677914 \\
3 & pair & A, B & -169.437210 \\
4 & pair & A, C & 35.6669284 \\
5 & pair & A, D & 32.5177869 \\
6 & pair & A, G & -7.63028325 \\
7 & pair & A, I & -14.2452458 \\
8 & pair & D, F & 49.6720676 \\
9 & triangle & A, C, D & 9.23083047 \\
10 & triangle & A, C, H & -4.42879532 \\
11 & triangle & A, D, F & -7.57793690 \\
12 & triangle & A, D, G & 9.23083049 \\
13 & triangle & A, G, I & 8.46502103 \\
14 & tetrahedron & A, D, F, G & -30.8648933 \\
\hline
\end{tabular}

丸で示した Nd のサイトは常に Ndが占有し，白丸で示した $\mathrm{Cu}, \mathrm{Fe}$ のサイトの配置のみが固溶によって入れ替わる構造モ デルを用い，配列の異なる計 38 個の規則構造のエネルギーを 第一原理計算から求め, CE-CVM 計算を行った。占有演算子 $\sigma_{\mathrm{i}}$ は Feがサイト i を占有した場合を 1 に，Cuが占有した場 合を 0 に取るよう定義した。また CE-CVM で考慮するクラ スターは 4 体のクラスターまでを含む計14個のクラスターを 選択した．計算に用いた各クラスターの構造と ECI の值を Table 1 に示した. サイトのアルファベットは Fig. 1の原子位 置に対応している。 これらの $\mathrm{ECI}$ を用いて $1000^{\circ} \mathrm{C}, 1250^{\circ} \mathrm{C}$, $1500^{\circ} \mathrm{C}$ における $\alpha \mathrm{Nd}(\mathrm{Fe}, \mathrm{Cu})$ 相の生成自由エネルギーを計算 し, 熱力学解析で用いた。

\section{2 自由エネルギーへの格子振動の寄与}

$\alpha \mathrm{Nd}(\mathrm{Fe}, \mathrm{Cu})$ 相の生成自由エネルギーを厳密に計算するた めには, 2.1. で求めた CE-CVM による自由エネルギーに対し て, さらに格子振動によるエントロピーを考慮する必要があ る. しかし全組成領域において, この格子振動の効果を取り 入れた計算を行うことは計算時間の問題から困難である。そ
こで本研究では, $\alpha \mathrm{Nd}(\mathrm{Fe}, \mathrm{Cu})$ 相の終端組成に対応する $\alpha \mathrm{NdFe}$ および $\alpha \mathrm{NdCu}$ の格子振動のエントロピーを評価し， 固溶領域ではその組成平均で近似してこの効果を考慮するこ とにした．実際の計算ではデバイ・グリユナイゼンモデル8-10) を用いて $\alpha \mathrm{NdFe}$ 相の有限温度における生成自由エネルギー を評価した.

この手法では，調和振動子によって格子振動を近似し，そ れにデバイ模型を適用することで，有限温度における振動の 効果を取り入れた自由エネルギーを計算する。まず，デバイ 温度とその体積依存性を定義するグリュナイゼン定数を求め るために，第一原理計算から $\alpha \mathrm{NdFe}$ 相の基底状態に打ける 生成エネルギーの体積依存性を求め, 求めた体積依存性を式 (1) に示した Morse ポテンシャルでフィッティングした.

$E(r)=A+D \cdot \exp \left\{-2 \lambda \cdot\left(r-r_{0}\right)\right\}-2 D \cdot \exp \left\{-\lambda \cdot\left(r-r_{0}\right)\right\} \quad(1)$ 式(1)中の $A, D, \lambda, r_{0}$ がフィッティングパラメータであり, Morse ポテンシャルでは対象とする相の体積を剛体球モデル で近似している，生成エネルギーの体積依存性より決定した 4 つのフィッティングパラメータより平衡体積 $\left(r=r_{0}\right)$ に打け る体積弾性率とデバイ温度はそれぞれ式 $(2)$ ，（3）のように 表される。

$$
\begin{gathered}
B\left(r_{0}\right)=\frac{D \lambda^{2}}{6 \pi r_{0}} \\
\Theta_{D\left(r=r_{0}\right)}=\left(48 \pi^{5}\right)^{\frac{1}{6}} \frac{\hbar}{k_{B}} k(v) \sqrt{\frac{r_{0} B\left(r_{0}\right)}{M}}
\end{gathered}
$$

ここでれはプランク定数を $2 \pi$ で除したディラック定数， $k_{B}$ はボルッマン定数, $M$ は対数平均原子量 ${ }^{10)}$ で $k(v)$ は式 $(4)$ で表されるポアソン比 $v$ の関数であり, 本研究ではポアソン 比を 0.25 として解析を行った。

$$
k(v)=\left[\frac{2}{3}\left\{\frac{2(1+v)}{3(1-2 v)}\right\}^{\frac{3}{2}}+\frac{1}{3}\left\{\frac{1+v}{3(1-v)}\right\}^{\frac{3}{2}}\right]^{\frac{1}{3}}
$$

これらのパラメータを用いることで，平衡体積における定積 比熱は式 ( 5 )によって導出できる。

$$
\begin{aligned}
C_{V\left(r=r_{0}\right)} & =\left(T, \Theta_{D\left(r=r_{0}\right)}\right)=3 R f_{D}\left(\frac{\Theta_{D\left(r=r_{0}\right)}}{T}\right) \\
& =3 R \cdot 3\left(\frac{T}{\Theta_{D\left(r=r_{0}\right)}}\right)^{3} \int_{0}^{\frac{\Theta_{D\left(r=r^{\prime}\right)}}{T}} \frac{e^{x} x^{4}}{\left(e^{x}-1\right)^{2}} d x
\end{aligned}
$$

ここで $f_{D}$ はデバイ関数である。デバイ温度の体積依存性を定 義するグリュナイゼン定数には, Dugdale ら ${ }^{11)}$ の值を用いた。 用いたグリュナイゼン定数 $\gamma$ はモースポテンシャルのフィッ ティングパラメータを用いて式 $(6)$ のように表すことができ る.

$$
\gamma=\frac{\lambda r_{0}}{2}
$$

このグリュナイゼン定数とデバイ温度との間には式 $(7)$ の うな関倸がある。

$$
\frac{\Theta_{D}}{\Theta_{D\left(r=r_{0}\right)}}=\left(\frac{V_{0}}{V}\right)^{\gamma}=\left(\frac{r_{0}}{r}\right)^{3 \gamma}
$$

式 $(7)$ より平衡体積以外のデバイ温度 $\Theta_{D}$ を導出でき, 各体 積におけるへルムホルッ自由エネルギーの温度依存性が式 (8)のように与えられる. 


$$
\begin{aligned}
F(T, V)= & E(V)+\frac{9}{8} R \Theta_{D} \\
& -R T\left[f_{D}\left(\frac{\Theta_{D}}{T}\right)-3 \ln \left\{1-\exp \left(-\frac{\Theta_{D}}{T}\right)\right\}\right]
\end{aligned}
$$

式（８）はヘルムホルツの自由エネルギーを表しているが，各 温度における $F(V)$ の極小点から有限温度における平衡体積を 求めると，その平衡体積における生成自由エネルギーは，各 体積が昇温にともなって変化する自由エネルギーと同義であ りギブスによる自由エネルギーである。 そこで本研究では, 各温度における式 $(8)$ の体積を変数とした際の極小值を求め るために式 (9)に示した Birch-Murnaghanの状態方程式 ${ }^{12)}$ を用いた。

$$
\begin{aligned}
F(V)=E\left(V_{0}\right)+\frac{9}{16}[ & B_{0} V_{0}\left\{\left(\frac{V_{0}}{V}\right)^{\frac{2}{3}}-1\right]^{3} B_{0}^{\prime} \\
& \left.+\left\{\left(\frac{V_{0}}{V}\right)^{\frac{2}{3}}-1\right]^{2}\left\{6-4\left(\frac{V_{0}}{V}\right)^{\frac{2}{3}}\right\}\right]
\end{aligned}
$$

ここで $E\left(V_{0}\right)$ は平衡体積 $V_{0}$ における基底状態の生成エネル ギー, $B_{0}$ は平衡体積における体積弾性率, $B_{0}^{\prime}$ は体積弾性率の 圧力に対する一階微分である。式 $(9)$ を用いたフィッティン グ解析より平衡体積が得られるので, 各温度の平衡体積にお ける生成自由エネルギーを熱力学解析に用いた。

\section{3 各相のギブス自由エネルギーの記述}

$\mathrm{Nd}-\mathrm{Fe}-\mathrm{Cu} 3$ 元系は液相 $(\mathrm{L})$, 一次固溶体相である bcc 相 $(\beta \mathrm{Nd}, \alpha \mathrm{Fe}, \delta \mathrm{Fe}), \quad \mathrm{fcc}$ 相 $(\gamma \mathrm{Fe}, \gamma \mathrm{Cu}), \operatorname{dhcp}$ 相 $(\alpha \mathrm{Nd})$, 金属間 化合物である $\mathrm{Nd}_{2} \mathrm{Fe}_{17}$ (空間群 $\left.R \overline{3} m\right)^{13)}, \mathrm{Nd}_{5} \mathrm{Fe}_{17}\left(P 6_{3} / m c m\right)^{14)}$, $\mathrm{NdCu}_{6}(P n m a)^{15)}, \mathrm{NdCu}_{5}(P 6 / m m m)^{16)}, \mathrm{NdCu}_{4}$ (結晶構造不 明), $\mathrm{Nd}_{2} \mathrm{Cu}_{7}$ (結晶構造不明), $\mathrm{NdCu}_{2}(\text { Imma })^{17)}, \alpha \mathrm{CuNd}$ $(P n m a)^{16)}, \beta \mathrm{CuNd}\left(\right.$ 結晶構造不明), $\delta\left(\mathrm{Nd}_{6} \mathrm{Fe}_{13} \mathrm{Cu}, I 4 / m \mathrm{~cm}\right)^{18)}$ から構成される。これらの各相のギブス自由エネルギーを以 下のように記述した。 なお，例えば $\beta \mathrm{Nd}, \alpha \mathrm{Fe}, \delta \mathrm{Fe}$ の各相は 同じ結晶構造であるため熱力学モデルの上では 1 つの相とし て取り扱っているが, 状態図の標記上は Fe-rich な領域の固 溶体を $(\alpha \mathrm{Fe}),(\delta \mathrm{Fe}), \mathrm{Nd}$-rich な領域の固溶体を $(\beta \mathrm{Nd})$ として 異なる記述を用いた. $(\gamma \mathrm{Fe}),(\gamma \mathrm{Cu})$ についても同様である.

\subsection{1 液相, 一次固溶体相の自由エネルギー}

本研究では液相, および bcc 相, fcc 相の各一次固溶体相の 自由エネルギーを正則溶体モデルによって記述した。 この記 述による 3 元系 $\phi$ 相 $(\phi=\mathrm{L}, \mathrm{bcc}, \mathrm{fcc}) 1 \mathrm{~mol}$ あたりのギブス自 由エネルギーは式(10)のように表すことができる.

$$
\begin{aligned}
G^{\phi} & =x_{\mathrm{Cu}}{ }^{\circ} G_{\mathrm{Cu}}^{\phi}+x_{\mathrm{Fe}}{ }^{\circ} G_{\mathrm{Fe}}^{\phi}+x_{\mathrm{Nd}}{ }^{\circ} G_{\mathrm{Nd}}^{\phi} \\
& +R T\left(x_{\mathrm{Cu}} \ln x_{\mathrm{Cu}}+x_{\mathrm{Fe}} \ln x_{\mathrm{Fe}}+x_{\mathrm{Nd}} \ln x_{\mathrm{Nd}}\right) \\
& +x_{\mathrm{Cu}} x_{\mathrm{Fe}} L_{\mathrm{Cu}, \mathrm{Fe}}^{\phi}+x_{\mathrm{Cu}} x_{\mathrm{Nd}} L_{\mathrm{Cu}, \mathrm{Nd}}^{\phi}+x_{\mathrm{Fe}} x_{\mathrm{Nd}} L_{\mathrm{Fe}, \mathrm{Nd}}^{\phi} \\
& +x_{\mathrm{Cu}} x_{\mathrm{Fe}} x_{\mathrm{Nd}} L_{\mathrm{Cu}, \mathrm{Fe}, \mathrm{Nd}}^{\phi}
\end{aligned}
$$

ここで $x_{i}$ は元素 $i$ のル分率, $R$ は気体定数, $T$ は絶対温度 である。 ${ }^{\circ} G_{i}^{\phi}$ は $\phi$ 相における元素 $i$ の自由エネルギーであり， 一般に lattice stability パラメータと呼ばれ, 絶対温度 $T$ の関 数として式(11)のように与えられる。

$$
\begin{aligned}
{ }^{\circ} G_{\mathrm{i}}^{\phi}-{ }^{\circ} H_{\mathrm{i}}^{\mathrm{ref}}= & A+B T+C T \ln T+D T^{2} \\
& +E T^{3}+F T^{7}+I T^{-1}+J T^{-9}
\end{aligned}
$$

ここで各係数 $A, B$ などは定数で, ${ }^{\circ} H_{\mathrm{i}}^{\mathrm{ref}}$ は $T=298 K$ における 基準状態での元素 $i$ の $1 \mathrm{~mol}$ あたりのエンタルピーである. 本 解析では, 各元素の lattice stability パラメータにDinsdale ${ }^{19)}$ による推奨值を用いた。 各元素のパラメータを Table 2 にま とめた. なお dhcp 相については元素の固溶を考慮せず, lattice stability パラメータのみで記述した。また，式(10)中の $L_{\mathrm{i}, \mathrm{j}}^{\phi}$ は $\phi$ 相における元素 $i$ と $j$ 間の相互作用パラメータであ り, Redlich-Kister ${ }^{20)}$ の多項式にしたがって，式(12)に示し た組成依存性を与えた。

$$
L_{\mathrm{i}, \mathrm{j}}^{\phi}={ }^{0} L_{\mathrm{i}, \mathrm{j}}^{\phi}+{ }^{1} L_{\mathrm{i}, \mathrm{j}}^{\phi}\left(x_{\mathrm{i}}-x_{\mathrm{j}}\right)+{ }^{2} L_{\mathrm{i}, \mathrm{j}}^{\phi}\left(x_{\mathrm{i}}-x_{\mathrm{j}}\right)^{2}+{ }^{3} L_{\mathrm{i}, \mathrm{j}}^{\phi}\left(x_{\mathrm{i}}-x_{\mathrm{j}}\right)^{3}
$$

さらに ${ }^{n} L_{\mathrm{i}, \mathrm{j}}^{\phi}$ には定数 $a^{\prime}, b^{\prime}$ および $c^{\prime}$ を用いて式(13)に示す温 度依存性を与えた。

$$
{ }^{n} L_{\mathrm{i}, \mathrm{j}}^{\phi}=a^{\prime}+b^{\prime} T+c^{\prime} T \ln T
$$

また式(10) 中の $L_{\mathrm{Cu}, \mathrm{Fe}, \mathrm{Nd}}^{\phi}$ は $\mathrm{Cu}, \mathrm{Fe}, \mathrm{Nd}$ 原子間の 3 元系相互作 用パラメータであり, Hillert ${ }^{21)}$ が提唱した式(14)を適用した.

$L_{\mathrm{Cu}, \mathrm{Fe}, \mathrm{Nd}}^{\phi}=x_{\mathrm{Cu}}{ }^{0} L_{\mathrm{Cu}, \mathrm{Fe}, \mathrm{Nd}}^{\phi}+x_{\mathrm{Fe}}{ }^{1} L_{\mathrm{Cu}, \mathrm{Fe}, \mathrm{Nd}}^{\phi}+x_{\mathrm{Nd}}{ }^{2} L_{\mathrm{Cu}, \mathrm{Fe}, \mathrm{Nd}}^{\phi} \quad(14)$ ${ }^{n} L_{\mathrm{Cu}, \mathrm{Fe}, \mathrm{Nd}}^{\phi}$ に対しては式(13)で示した 2 元系の相互作用パラ メータと同様の温度依存性を与えた。

\subsection{2 化学量論化合物相}

2 元系化学量論化合物相である $\mathrm{Nd}_{2} \mathrm{Fe}_{17}, \mathrm{Nd}_{5} \mathrm{Fe}_{17}, \mathrm{NdCu}_{6}$, $\mathrm{NdCu}_{5}, \mathrm{NdCu}_{4}, \mathrm{Nd}_{2} \mathrm{Cu}_{7}, \mathrm{NdCu}_{2}$ および 3 元系 $\delta$ 相については, 副格子モデル22) による化学量論化合物として自由エネルギー を表した。例えば化学量論化合物 $\mathrm{Nd}_{\mathrm{n}} \mathrm{Fe}_{\mathrm{m}}$ 相 $1 \mathrm{~mol}$ あたりの 自由エネルギーは式(15)のように記述できる.

$$
\begin{aligned}
& G_{\mathrm{Fe}: \mathrm{Nd}}^{\mathrm{Fe}_{\mathrm{m}} \mathrm{Nd}_{\mathrm{n}}}-m^{\circ} G_{\mathrm{Fe}}^{\mathrm{ref}}-n^{\circ} G_{\mathrm{Nd}}^{\mathrm{ref}} \\
& =A+B T+C T \ln T+D T^{2}+E T^{3} \ldots
\end{aligned}
$$

ここで ${ }^{\circ} G_{\mathrm{i}: \mathrm{j}}^{\phi}$ は第 1 副格子を $\mathrm{i}$ が，第 2 副格子を $\mathrm{j}$ が占有して いる規則構造 $\phi$ 相のギブス自由エネルギーであり，“：”は各 副格子の区切りを表している。 また $G_{\mathrm{i}}^{\mathrm{ref}},{ }^{\circ} G_{\mathrm{j}}^{\mathrm{ref}}$ はそれぞれ, 基 準状態で安定な構造の元素 i， j 1 mol あたりのギブス自由エ ネルギーである。

\subsection{3 $\alpha \mathrm{NdCu}, \beta \mathrm{NdCu}$ 相}

$\alpha \mathrm{NdCu}, \beta \mathrm{NdCu}$ 相については， $\mathrm{Cu}$ サイトに対する $\mathrm{Fe} の$ 置換型固溶を考慮した 2 副格子モデル $(\mathrm{Cu}, \mathrm{Fe})_{0.5}(\mathrm{Nd})_{0.5}$ を適 用した。この熱力学モデルを用いると，例えば $\alpha \mathrm{NdCu}$ 相 1 mol あたりのギブス自由エネルギーは式(16)で記述できる.

$$
\begin{aligned}
G^{\alpha(\mathrm{Cu}, \mathrm{Fe}) \mathrm{Nd}}= & y_{\mathrm{Cu}}^{(1)} G_{\mathrm{Cu}: \mathrm{Nd}}^{\alpha(\mathrm{Cu}) \mathrm{Nd}}+y_{\mathrm{Fe}}^{(1)} G_{\mathrm{Fe}: \mathrm{Nd}}^{\alpha(\mathrm{Cu}, \mathrm{Fe}) \mathrm{Nd}} \\
& +0.5 R T\left(y_{\mathrm{Cu}}^{(1)} \ln y_{\mathrm{Cu}}^{(1)}+y_{\mathrm{Fe}}^{(1)} \ln y_{\mathrm{Fe}}^{(1)}\right) \\
& +y_{\mathrm{Cu}}^{(1)} y_{\mathrm{Fe}}^{(1)} L_{\mathrm{Cu}, \mathrm{Fe}: \mathrm{Nd}}^{\alpha(\mathrm{Nu}, \mathrm{Ne}}
\end{aligned}
$$

ここで $y_{\mathrm{i}}^{(n)}$ は第 $\mathrm{n}$ 副格子における $\mathrm{i}$ 原子の格子占有率であり， $L$ は各副格子中での異種原子間の相互作用パラメータである. また $L$ 中の添字“,”は同じ副格子中での元素の区切りを表し ている.

\subsection{4 自由エネルギーに対する磁気変態の寄与}

磁気変態を有する相のギブス自由エネルギーは，式(17)に示 すように, 非磁性項 $G_{\mathrm{nonmag}}^{\phi}$ に磁性項 $G_{\mathrm{mag}}^{\phi}$ を加えて記述した. 
Table 2 Lattice stability parameters for $\mathrm{Nd}, \mathrm{Fe}$ and $\mathrm{Cu}$. The unit of energy is expressed in 1 mole of atoms.

\begin{tabular}{|c|c|c|c|c|}
\hline Element & Phase & & Thermodynamic parameters & Temperature, $T / \mathrm{K}$ \\
\hline \multirow{16}{*}{$\mathrm{Nd}$} & \multirow{3}{*}{ (L) } & \multirow{3}{*}{${ }^{\circ} G_{\mathrm{Nd}}^{(\mathrm{L})}-{ }^{\circ} H_{\mathrm{Nd}}^{\alpha \mathrm{Nd}}$} & $=-3351.187+109.517314 T-27.0858 T \ln T+0.556125 \times 10^{-3} T^{2}-2.6923 \times 10^{-6} T^{3}+34887 T^{-1}$ & $298.15<T<300$ \\
\hline & & & $=5350.01-86.593963 T+5.357301 T \ln T-46.955463 \times 10^{-3} T^{2}-6.860782 \times 10^{-6} T^{3}+374380 T^{-1}$ & $300<T<1128$ \\
\hline & & & $=-16335.232+268.625903 T-48.7854 T \ln T$ & $1128<T<1800$ \\
\hline & \multirow{4}{*}{$(\alpha \mathrm{Nd})$} & \multirow{4}{*}{${ }^{\circ} G_{\mathrm{Nd}}^{(\alpha \mathrm{Nd})}-{ }^{\circ} H_{\mathrm{Nd}}^{(\alpha \mathrm{Nd})}$} & $=-8402.93+111.10239 T-27.0858 T \ln T+0.556125 \times 10^{-3} T^{2}-2.6923 \times 10^{-6} T^{3}+34887 T^{-1}$ & $298.15<T<900$ \\
\hline & & & $=-6984.083+83.662617 T-22.7536 T \ln T-4.20402 \times 10^{-3} T^{2}-1.802 \times 10^{-6} T^{3}$ & $900<T<1128$ \\
\hline & & & $=-225610.846+1673.040749 T-238.1828733 T \ln T+78.615997 \times 10^{-3} T^{2}-6.048207 \times 10^{-6} T^{3}+38810350 T^{-1}$ & $1128<T<1799$ \\
\hline & & & $=-25742.331+276.257088 T-48.7854 T \ln T$ & $1799<T<1800$ \\
\hline & \multirow{5}{*}{$(\beta \mathrm{Nd})$} & \multirow{5}{*}{${ }^{\circ} G_{\mathrm{Nd}}^{(\beta \mathrm{Nd})}-{ }^{\circ} H_{\mathrm{Nd}}^{(\alpha \mathrm{Nd})}$} & $=-6965.635+110.556109 T-27.0858 T \ln T+0.556125 \times 10^{-3} T^{2}-2.6923 \times 10^{-6} T^{3}+34887 T^{-1}$ & $298.15<T<400$ \\
\hline & & & $=7312.2-153.033976 T+14.9956777 T \ln T-50.479 \times 10^{-3} T^{2}-7.287217 \times 10^{-6} T^{3}-831810 T^{-1}$ & $400<T<1128$ \\
\hline & & & $=-18030.266+239.677322 T-44.5596 T \ln T$ & $1128<T<1289$ \\
\hline & & & $=334513.017-2363.919899 T+311.409193 T \ln T-156.030778 \times 10^{-3} T^{2}+12.408421 \times 10^{-6} T^{3}-64319604 T^{-1}$ & $1289<T<1799$ \\
\hline & & & $=-24495.579+274.879155 T-48.7854 T \ln T$ & $1799<T<1800$ \\
\hline & \multirow{4}{*}{$(\gamma \mathrm{Fe}, \gamma \mathrm{Cu})$} & \multirow{4}{*}{${ }^{\circ} G_{\mathrm{Nd}}^{(\gamma \mathrm{Fe}, \gamma \mathrm{Cu})}-{ }^{\circ} H_{\mathrm{Nd}}^{(\alpha \mathrm{Nd})}$} & $=-7902.93+111.10239 T-27.0858 T \ln T+0.556125 \times 10^{-3} T^{2}-2.6923 \times 10^{-6} T^{3}+34887 T^{-1}$ & $298.15<T<900$ \\
\hline & & & $=-6484.083+83.662617 T-22.7536 T \ln T-4.20402 \times 10^{-3} T^{2}-1.802 \times 10^{-6} T^{3}$ & $900<T<1128$ \\
\hline & & & $=-225110.846+1673.040749 T-238.1828733 T \ln T+78.615997 \times 10^{-3} T^{2}-6.048207 \times 10^{-6} T^{3}+38810350 T^{-1}$ & $1128<T<1799$ \\
\hline & & & $=-25242.331+276.257088 T-48.7854 T \ln T$ & $1799<T<1800$ \\
\hline \multirow{8}{*}{$\mathrm{Fe}$} & \multirow{2}{*}{ (L) } & \multirow{2}{*}{${ }^{\circ} G_{\mathrm{Fe}}^{(\mathrm{L})}-{ }^{\circ} H_{\mathrm{Fe}}^{(\alpha \mathrm{Fe})}$} & $=13265.87+117.57557 T-23.5143 T \ln T-4.39752 \times 10^{-3} T^{2}-0.058927 \times 10^{-6} T^{3}+77359 T^{-1}-3.67516 \times 10^{-21} T^{7}$ & $298.15<T<1811$ \\
\hline & & & $=-10838.83+291.302 T-46 T \ln T$ & $1811<T<6000$ \\
\hline & \multirow{3}{*}{$(\alpha \mathrm{Fe})$} & \multirow{3}{*}{${ }^{\circ} G_{\mathrm{Fe}}^{(\alpha \mathrm{Fe})}-{ }^{\circ} H_{\mathrm{Fe}}^{(\alpha \mathrm{Fe})}$} & $=1225.7+124.134 T-23.5143 T \ln T-4.39752 \times 10^{-3} T^{2}-0.058927 \times 10^{-6} T^{3}+77359 T^{-1}$ & $298.15<T<1811$ \\
\hline & & & $=-25383.581+299.31255 T-46 T \ln T+2.29603 \times 10^{31} T^{-9}$ & $1811<T<6000$ \\
\hline & & & $T_{\mathrm{cFe}}^{(\alpha \mathrm{Fe})}=1043, \quad \beta_{\mathrm{Fe}}^{(\alpha \mathrm{Fe})}=2.22$ & $298.15<T<6000$ \\
\hline & \multirow{3}{*}{$(\gamma \mathrm{Fe})$} & \multirow{3}{*}{${ }^{\circ} G_{\mathrm{Fe}}^{(\gamma \mathrm{Fe})}-{ }^{\circ} H_{\mathrm{Fe}}^{(\alpha \mathrm{Fe})}$} & $=-236.7+132.416 T-24.6643 T \ln T-3.75752 \times 10^{-3} T^{2}-0.058927 \times 10^{-6} T^{3}+77359 T^{-1}$ & $298.15<T<1811$ \\
\hline & & & $=-27097.396+300.252559 T-46 T \ln T+2.78854 \times 10^{31} T^{-9}$ & $1811<T<6000$ \\
\hline & & & $T_{\mathrm{cFe}}^{(\gamma \mathrm{Fe})}=-201, \quad \beta_{\mathrm{Fe}}^{(\gamma \mathrm{Fe})}=-2.1$ & $298.15<T<6000$ \\
\hline \multirow{6}{*}{$\mathrm{Cu}$} & \multirow{2}{*}{ (L) } & \multirow{2}{*}{${ }^{\circ} G_{\mathrm{Cu}}^{(\mathrm{L})}-{ }^{\circ} H_{\mathrm{Cu}}^{(\gamma \mathrm{Cu})}$} & $=5194.277+120.973331 T-24.112392 T \ln T-2.65684 \times 10^{-3} T^{2}+1.29223 \times 10^{-7} T^{3}+52478 T^{-1}-5.8489 \times 10^{-21} T^{7}$ & $298.15<T<1357.77$ \\
\hline & & & $=-46.545+173.881484 T-31.38 T \ln T$ & $1357.77<T<3200$ \\
\hline & \multirow{2}{*}{$(\gamma \mathrm{Cu})$} & \multirow{2}{*}{${ }^{\circ} G_{\mathrm{Cu}}^{(\gamma \mathrm{Cu})}-{ }^{\circ} H_{\mathrm{Cu}}^{(\gamma \mathrm{Cu})}$} & $=-7770.458+130.485235 T-24.112392 T \ln T-2.65684 \times 10^{-3} T^{2}+1.29223 \times 10^{-7} T^{3}+52478 T^{-1}$ & $298.15<T<1357.77$ \\
\hline & & & $=-13542.026+183.803828 T-31.38 T \ln T+3.64167 \times 10^{29} T^{-9}$ & $1357.77<T<3200$ \\
\hline & \multirow{2}{*}{$(\beta \mathrm{Nd}, \alpha \mathrm{Fe})$} & \multirow{2}{*}{${ }^{\circ} G_{\mathrm{Cu}}^{(\mathrm{BNd}, \alpha \mathrm{Fe})}-{ }^{\circ} H_{\mathrm{Cu}}^{(\gamma \mathrm{Cu} u}$} & $=-3753.458+129.230235 T-24.112392 T \ln T-2.65684 \times 10^{-3} T^{2}+1.29223 \times 10^{-7} T^{3}+52478 T^{-1}$ & $298.15<T<1357.77$ \\
\hline & & & $=-9525.026+182.548828 T-31.38 T \ln T+3.64167 \times 10^{29} T^{-9}$ & $1357.77<T<3200$ \\
\hline
\end{tabular}

$$
G^{\phi}=G_{\mathrm{nonmag}}^{\phi}+G_{\mathrm{mag}}^{\phi}
$$

ここで磁性項 $G_{\mathrm{mag}}^{\phi}$ については Inden ${ }^{23)}$ が提唱し, Hillert ら ${ }^{24)}$ によって修正された式 $(18)$ を用いた。

$$
G_{\mathrm{mag}}^{\phi}=R T \cdot f(\tau) \ln (\beta+1)
$$

式(18)中の $\tau$ は, 合金の磁気変態温度 $T_{c}$ を用いて $T / T_{c}$ と定 義される值で, $\beta$ は合金のボーア磁子数を示す．また関数 $f(\tau)$ は式(19)，（20)のように表すことができる.

$$
f(\tau)=1-\frac{1}{A}\left\{\frac{79 \tau^{-1}}{140 p}+\frac{474}{497}\left(\frac{1}{p}-1\right)\left(\frac{\tau^{3}}{6}+\frac{\tau^{9}}{135}+\frac{\tau^{15}}{600}\right)\right\} \quad \text { for } \tau<1
$$

$$
f(\tau)=-\frac{1}{A}\left(\frac{\tau^{-5}}{10}+\frac{\tau^{-15}}{315}+\frac{\tau^{-25}}{1500}\right) \quad \text { for } \tau \geq 1
$$

ここで A は式(21)のように表される.

$$
A=\frac{518}{1125}+\frac{11692}{15975}\left(\frac{1}{p}-1\right)
$$

式(21)において $p$ は結晶構造に依存するパラメータであり,

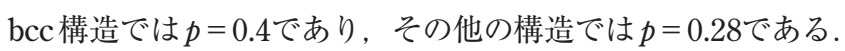

\section{3. 計算結果と考察}

\section{1 熱力学的解析}

本節では, はじめに $\mathrm{Nd}-\mathrm{Fe}-\mathrm{Cu} 3$ 元系を構成する各 2 元系 と 3 元系の実験情報を整理し, 相平衡の概要を説明する。さ らに $\mathrm{Nd}-\mathrm{Fe} 2$ 元系と $\mathrm{Nd}-\mathrm{Fe}-\mathrm{Cu} 3$ 元系に関する熱力学的解析 の結果を述べる。

\subsubsection{Nd-Fe 2 元系}

この 2 元系についての文献集録が Zhang ら ${ }^{25)}$, Hallemans $ら^{26)}$, Okamoto ${ }^{27)}$, Marazza ら ${ }^{28)} に よ り$ 行なわれている.こ れらによれば, $\mathrm{Nd}-\mathrm{Fe} 2$ 元系は液相 $(\mathrm{L}),(\alpha \mathrm{Fe}),(\gamma \mathrm{Fe}),(\delta \mathrm{Fe})$, $(\alpha \mathrm{Nd}),(\beta \mathrm{Nd})$ の各一次固溶体, $\mathrm{Nd}_{2} \mathrm{Fe}_{17}(R \overline{3} m), \mathrm{Nd}_{5} \mathrm{Fe}_{17}\left(P 6_{3} /\right.$ $m \mathrm{~cm})$ から構成されている.

まず相境界については, Terekhova ら ${ }^{29)}$ が熱分析と X 線回 折法 (X-ray Diffraction. 以下 XRD とする)により広い組成範 囲での相境界を調べている. 彼らの実験ではラーベス型 $\mathrm{NdFe}_{2}$ 相の存在が報告されているが, その後の Faudot ら ${ }^{30)} に$ よる示差熱分析 (Differential Thermal Analysis. 以下 DTA と 
する)の実験では確認されていない。またCannon ら ${ }^{31)} は$ $1000^{\circ} \mathrm{C}, 2 \mathrm{GPa}$ から $2.8 \mathrm{GPa}$ の高圧においてこの相の生成を 確認しているが，大気圧ではこの相は出現しない32-34)ことか ら, 現在ではこの相は準安定構造とみなされている ${ }^{25)}$.

Faudot $5^{30)}$ は希土類元素の酸化防止のために高純度金属を 用いたDTA と XRD によって不変系温度や液相線を測定し, $684.5^{\circ} \mathrm{C}, 23.5$ at. $\% \mathrm{Fe}$ で共晶反応が, $1210^{\circ} \mathrm{C}$, 約 67 at. \% Fe (液相組成)で包晶反応が起こることを報告している。一方, Che ら ${ }^{35)}$ が XRD とDTA，磁気測定法により調べた $(\mathrm{L}) \Leftrightarrow$ $(\alpha \mathrm{Nd})+\mathrm{Nd}_{2} \mathrm{Fe}_{17}$ の共晶反応は $647^{\circ} \mathrm{C}, 25$ at. $\% \mathrm{Nd}, \quad(\mathrm{L})+$ $(\gamma \mathrm{Fe}) \Leftrightarrow \mathrm{Nd}_{2} \mathrm{Fe}_{17}$ の包晶温度は $1190^{\circ} \mathrm{C}$ であり, Faudotらの結果 とわずかに違っている. またChe らは $\mathrm{NdFe}_{2}, \mathrm{Nd}_{5} \mathrm{Fe}_{17}$ 相を 検出していない. Schneider ら ${ }^{36)}$ も同様の実験的手法により 相境界を測定し, 包晶温度を $1210 \pm 5^{\circ} \mathrm{C}$, 共晶温度を $684^{\circ} \mathrm{C}$ と 報告した。ささにDTAの試料の中に $\varepsilon$ 相と呼ばれる一軸結晶 磁気異方性を示す化合物の生成を認めているが, これは凝固 時に混入した酸素の影響である可能性を指摘している.

Landgraf ら ${ }^{37)}$ はDTA と光学顕微鏡観察により状態図の研 究を行い, $\mathrm{Nd}_{2} \mathrm{Fe}_{17}$ 以外に 2 つの相がこの 2 元系の試料中に現 れることを見出した。一つは Schneider ら ${ }^{36)}$ が $\varepsilon$ 相と呼んだ 構造に該当するものと考えられる。もう一つは $875 \mathrm{~K}\left(602^{\circ} \mathrm{C}\right)$ で50日以上熱処理した10-80 at.\% Fe の組成範囲に現れる相 で, これは Schneider ${ }^{38)}$ が $\pi$, あるいは Ping ら ${ }^{39)}$ が報告して いる相に該当すると述べている. Moreau ら ${ }^{14)}$ は, この相が $\mathrm{Nd}_{5} \mathrm{Fe}_{17}$ の組成を持つ六方晶構造の単位胞の化合物であること を確認した。この相の安定性についても酸素の影響が疑われ るが, Landgraf らはその影響は小さく, むしろ反応性が極め て遅いためにこれまで 2 元系で確認されていなかった安定相 であると考えた。この $\mathrm{Nd}_{5} \mathrm{Fe}_{17}$ の関与により $(\alpha \mathrm{Nd})$ と $\mathrm{Nd}_{5} \mathrm{Fe}_{17}$ の共晶反応が $680^{\circ} \mathrm{C} て ゙$ 起こり, 等温時効によりこの相が $770^{\circ} \mathrm{C}$ から $795^{\circ} \mathrm{C}$ の間の温度において生成すること，この共晶組成は 20 から 30 at.\% Feの範囲であることを推定した。さらに Hennemann ら ${ }^{40)}$ は起電力測定法によって Nd-rich 側での Nd の活量を測定し, 得られた活量曲線に出現した 2 種類のプラ トーから $\mathrm{Nd}_{5} \mathrm{Fe}_{17}$ の存在を確認した.この結果を用いて $\mathrm{Nd}_{2} \mathrm{Fe}_{17}$ と $\mathrm{Nd}_{5} \mathrm{Fe}_{17}$ の生成自由エネルギーを, $973 \mathrm{~K}\left(700^{\circ} \mathrm{C}\right)$ で それぞれ各化合物 $1 \mathrm{~mol}$ あたり $-46,-52 / \mathrm{kJ}$ と決定している. この他にも $\mathrm{Nd}_{2} \mathrm{Fe}_{17}$ の生成自由エネルギーに関しては Xi， $\mathrm{Ji}^{41)}$, Gozzi ら ${ }^{42)}$ が起電力測定法, Nagai ら ${ }^{43)}$ がクヌーセンセル法 によって测定しており，298 Kにおける生成エンタルピーは Meschel ら ${ }^{44)} に よ っ て$ 直接合成熱量測定法を用いて測定され ている. 熱力学的性質については他に, Nagai ら ${ }^{43)}$ がクヌー センセル法によって Nd の活量を, Ivanov ら ${ }^{45)}$ が等温壁型熱 量計を用いて $1829 \mathrm{~K}\left(1556^{\circ} \mathrm{C}\right)$ における液相の混合エンタル ピーを報告している.

これ以外にも, He ら ${ }^{46)} に よ る$ 陽電子消滅法, Zhang ら ${ }^{47)}$ によるXRD と電子線マイクロアナライザ(Electron Probe Micro Analyser. 以下 EPMA とする)法，同じく EPMA 法を用 いた Li, Xing ${ }^{48)}$ によって Fe 中への $\mathrm{Nd}$ の固溶度の測定が行 なわれている。また $\mathrm{Nd}_{2} \mathrm{Fe}_{17}$ と $\mathrm{Nd}_{5} \mathrm{Fe}_{17}$ はそれぞれ599〜 $610^{\circ} \mathrm{C}^{49-51)}, 776 \sim 780^{\circ} \mathrm{C}^{37,52,53)}$ の強磁性転移温度と, 各化合物 $1 \mathrm{~mol}$ あたり $28 \mu_{B}{ }^{49)}, 46.5 \mu_{B}{ }^{52)}$ の磁気モーメントの值が報
告されている.

本研究ではこれらの実測值に基づいて $\mathrm{Nd}-\mathrm{Fe} 2$ 元系の熱力 学的解析を行った. $\mathrm{Nd}_{5} \mathrm{Fe}_{17}$ については一部の状態図には安定 相として記載されていないものもあるが, Landgraf ら ${ }^{37)}$ がき わめて長時間熱処理した試料に出現しており, Hennemann ら ${ }^{40)} も こ の$ 事実を確認してその生成エネルギーを決定してい ることから, 本研究ではこの相を安定構造として解析に取り 入れた. この 2 元系の熱力学的解析は Schneider ら ${ }^{36)}$, Hennemann $ら^{40)}$, Hallemans ${ }^{26)}$, Van Ende ら ${ }^{54)} に よ り$ 行 なわれている. しかし Schneider ら ${ }^{36)}$ の解析では $\mathrm{Nd}_{5} \mathrm{Fe}_{17}$ が 考慮されていない. そこで本研究では Hennemann ら ${ }^{40)}$, Hallemans $ら^{26)}$, Van Ende $5^{54)}$ のパラメータを参照しなが ら, 液相線温度や不変系反応に関する実験情報にさらによく 一致するように熱力学パラメー夕を再検討した。 また最も新 しいV Van Ende らの解析 ${ }^{54)}$ は, 液相に対して修正擬化学モデ ルを適用しているので, 本研究では他の合金系との整合性を 考慮してこの解析結果を採用しなかった．解析にあたっては， Terekhova ${ }^{29)}$ の実験值は他の測定值からの逸脱があるため, 熱力学的解析においてはできるだけ最新の実験值 ${ }^{30,36,37,40)}$ 重視した。また過剩磁気ギブスエネルギー項に関しては $\mathrm{Nd}_{2} \mathrm{Fe}_{17}$ と $\mathrm{Nd}_{5} \mathrm{Fe}_{17}$ それぞれの磁気変態を考慮している先行研 究の值 ${ }^{26)}$ を用いた。 得られた $\mathrm{Nd}-\mathrm{Fe} 2$ 元系の熱力学パラメー 夕を Table 3 に示した。 これを用いて計算した 2 元系状態図 を相境界の実験值 ${ }^{29,30,36,37,40)}$ および Hallemans ら ${ }^{26)}$ のパラメー 夕を用いた計算結果とともに Fig. 2 に示した. また本研究で 得られたパラメータで計算した $\mathrm{Nd}_{2} \mathrm{Fe}_{17}$ と $\mathrm{Nd}_{5} \mathrm{Fe}_{17}$ のギブス自 由エネルギーを, 先行解析のパラメータ26,54) および実験 值 ${ }^{40-43)}$ と Fig. 3 および Fig. 4 において比較した. 本研究では 高温域の Nagai ら ${ }^{43)}$ の実験結果を用いてパラメータを評価し たため, Van Ende ら ${ }^{54)}$ や Hennemann ら ${ }^{40)}$ の結果からは乘 離した. そこで解析結果の妥当性を検討するために, $\mathrm{Nd}_{2} \mathrm{Fe}_{17}$ と $\mathrm{Nd}_{5} \mathrm{Fe}_{17}$ と平衡する相である液相の混合エンタルピーの実 験值 ${ }^{45)}$ を本研究結果と Fig. 5 において比較した。この図より 本研究で評価したパラメータは実験值をよく再現しているこ とから, 液相と平衡する $\mathrm{Nd}_{2} \mathrm{Fe}_{17}$ と $\mathrm{Nd}_{5} \mathrm{Fe}_{17}$ についても正しく 評価されていると考えられる。 さらに $\mathrm{Nd}_{2} \mathrm{Fe}_{17}$ の生成エンタ ルピー $\Delta H_{298}^{0}{ }^{44)}$ の実験值は $-3.0 \pm 3.7 \mathrm{~kJ} / \mathrm{mol}$ of atoms である のに対し, 本研究結果は $-680.7 \mathrm{~J} / \mathrm{mol}$ of atoms であり, エ ラーバーを考慮すれば比較的良い一致を示していると考えら れる. Fig. 6 では， Ndの活量の実験結果 ${ }^{43)}$ を計算結果と比 較した。

\subsubsection{Nd-Cu 2 元系}

$\mathrm{Nd}-\mathrm{Cu} 2$ 元系は液相 $(\mathrm{L}),(\alpha \mathrm{Nd}),(\beta \mathrm{Nd}),(\gamma \mathrm{Cu})$ の各一次 固溶体, $\mathrm{NdCu}(\alpha \mathrm{NdCu}, \beta \mathrm{NdCu}), \mathrm{NdCu}_{2}, \mathrm{Nd}_{2} \mathrm{Cu}_{7}, \mathrm{NdCu}_{4}$, $\mathrm{NdCu}_{5}, \mathrm{NdCu}_{6}$ の化合物により構成されている. この 2 元系に ついては, 相境界 ${ }^{16,55-57)}$ の実験的測定の他に, 熱力学的性質 については, $\mathrm{NdCu}_{6}, \mathrm{NdCu}_{2}$ の融解熱, 融解エントロピー, 熱 力学計算による液相の過剩自由エネルギー変化 ${ }^{58)}, \mathrm{NdCu}$ の 同素変態 $\left(\alpha\right.$ および $\beta \mathrm{NdCu}$ 温度の測定 $\left.{ }^{59}\right), \mathrm{NdCu}_{6}, \mathrm{NdCu}_{2}$ の生 成エンタルピーの測定 ${ }^{60)}$, 液相の混合エンタルピー60,61) など の報告がある.

これらの実験報告に基づいた 2 元系の熱力学的解析は $\mathrm{Du}$ 
Table 3 Optimized thermodynamic parameters of the binary and ternary systems. The unit of energy is expressed in 1 mole of atoms.

\begin{tabular}{|c|c|c|c|}
\hline System & Phase & Thermodynamic parameters & Ref. \\
\hline \multirow{11}{*}{$\mathrm{Nd}-\mathrm{Fe}$} & \multirow{2}{*}{ (L) } & ${ }^{0} L_{\mathrm{Fe}, \mathrm{Nd}}^{(\mathrm{L})}=-3499+6.99 T$ & \multirow{6}{*}{ Present work } \\
\hline & & ${ }^{1} L_{\mathrm{Fe}, \mathrm{Nd}}^{(\mathrm{L})}=-3137+6.63 T$ & \\
\hline & \multirow{2}{*}{$(\beta \mathrm{Nd}, \alpha \mathrm{Fe})$} & ${ }^{0} L_{\mathrm{Fe}, \mathrm{Nd}}^{(\beta \mathrm{Nd})}=87958-36.74 T$ & \\
\hline & & ${ }^{1} L_{\mathrm{Fe}, \mathrm{Nd}}^{(\beta \mathrm{Nd})}=-54128+36.49 T$ & \\
\hline & $(\gamma \mathrm{Fe})$ & ${ }^{0} L_{\mathrm{Fe}, \mathrm{Nd}}^{(\gamma \mathrm{Fe})}=21572+6.778 T$ & \\
\hline & \multirow{2}{*}{$\mathrm{Nd}_{2} \mathrm{Fe}_{17}$} & ${ }^{0} G_{\mathrm{Fe}: \mathrm{Nd}}^{\mathrm{Nd}_{2} \mathrm{~F}_{17}}-0.1053{ }^{0} G_{\mathrm{Nd}}^{(\alpha \mathrm{Nd})}-0.8947{ }^{0} G_{\mathrm{Fe}}^{(\alpha \mathrm{Fe})}=-7477.2+5.856 T-0.2883 T \ln T$ & \\
\hline & & ${ }^{0} T_{\mathrm{CFe}: \mathrm{Nd}}^{\mathrm{Nd}_{2} \mathrm{Fe}_{77}}=327.15, \quad{ }^{0} \beta_{\mathrm{Fe}: \mathrm{Nd}^{2}}^{\mathrm{Nd}_{2} \mathrm{Fe}_{7}}=2.3$ & 26) \\
\hline & \multirow{2}{*}{$\mathrm{Nd}_{5} \mathrm{Fe}_{17}$} & ${ }^{0} G_{\mathrm{Fe}: \mathrm{Nd}}^{\mathrm{Nd}_{\mathrm{d}} \mathrm{Fe}_{17}}-0.2273{ }^{0} G_{\mathrm{Nd}}^{(\alpha \mathrm{Nd})}-0.7727{ }^{0} G_{\mathrm{Fe}}^{(\alpha \mathrm{Fe})}=-5947.61+1.99 T+0.0884 T \ln T$ & Present work \\
\hline & & ${ }^{0} T_{\mathrm{CF}: \mathrm{Nd}}^{\mathrm{Nd} \mathrm{Fe}_{17}}=503.15, \quad{ }^{0} \beta_{\mathrm{Fe}: \mathrm{Nd} d}^{\mathrm{Nd}_{\mathrm{N}} \mathrm{Fe}_{17}}=2.3$ & 26) \\
\hline & $\alpha \mathrm{NdFe}$ & ${ }^{0} G_{\mathrm{Fe}: \mathrm{Nd}}^{\alpha \mathrm{Nde}}-0.5{ }^{0} G_{\mathrm{Nd}}^{(\alpha \mathrm{Nd})}-0.5{ }^{0} G_{\mathrm{Fe}}^{(\alpha \mathrm{Fe})}=9108-50.85 T+8.71 T \ln T$ & \multirow{2}{*}{ Present work } \\
\hline & $\beta \mathrm{NdFe}$ & ${ }^{0} G_{\mathrm{Fe}: \mathrm{Nd}}^{\beta \mathrm{NNe}}-0.5{ }^{0} G_{\mathrm{Nd}}^{(\alpha \mathrm{Nd})}-0.5{ }^{0} G_{\mathrm{Fe}}^{(\alpha \mathrm{Fe})}=9108-50.85 T+8.71 T \ln T$ & \\
\hline \multirow{10}{*}{$\mathrm{Nd}-\mathrm{Cu}$} & \multirow{3}{*}{ (L) } & ${ }^{0} L_{\mathrm{Cu}, \mathrm{Nd}}^{(\mathrm{L})}=-55583.6+5.8955 T-2.4901 T \ln T$ & \multirow{10}{*}{ 55) } \\
\hline & & ${ }^{1} L_{\mathrm{Cu}, \mathrm{Nd}}^{(\mathrm{L})}=-27795.1+3.1830 T-1.2911 T \ln T$ & \\
\hline & & ${ }^{2} L_{\mathrm{Cu}, \mathrm{Nd}}^{(\mathrm{L})}=-3806$ & \\
\hline & $\mathrm{NdCu}_{6}$ & ${ }^{0} G_{\mathrm{Cu}: \mathrm{Nd}}^{\mathrm{Ndd} \mathrm{u}_{6}}-0.1429^{0} G_{\mathrm{Nd}}^{(\alpha \mathrm{Nd})}-0.8571{ }^{\circ} G_{\mathrm{Cu}}^{(\gamma \mathrm{Cu})}=13581.0-0.7253 T$ & \\
\hline & $\mathrm{NdCu}_{5}$ & ${ }^{0} G_{\mathrm{Cu}: \mathrm{Nd}}^{\mathrm{NdCu}}-0.1667{ }^{0} G_{\mathrm{Nd}}^{(\alpha \mathrm{Nd})}-0.8333{ }^{0} G_{\mathrm{Cu}}^{(\gamma \mathrm{Cu})}=-15704.5-0.1205 T$ & \\
\hline & $\mathrm{NdCu}_{4}$ & ${ }^{0} G_{\mathrm{Cu}: \mathrm{Nd}}^{\mathrm{Nd} \mathrm{U}_{4}}-0.2{ }^{0} G_{\mathrm{Nd}}^{(\alpha \mathrm{Nd})}-0.8{ }^{0} G_{\mathrm{Cu}}^{(\gamma \mathrm{Cu})}=-16826.7-0.1695 T$ & \\
\hline & $\mathrm{Nd}_{2} \mathrm{Cu}_{7}$ & ${ }^{0} G_{\mathrm{Cu}: \mathrm{Nd}}^{\mathrm{Nd} \mathrm{Cu}_{7}}-0.2222{ }^{0} G_{\mathrm{Nd}}^{(\alpha \mathrm{Nd})}-0.7778{ }^{0} G_{\mathrm{Cu}}^{(\gamma \mathrm{Cu})}=-10046.4-7.2194 T$ & \\
\hline & $\mathrm{NdCu}_{2}$ & ${ }^{0} G_{\mathrm{Cu}: \mathrm{Nd} d}^{\mathrm{NdC}}-0.3333{ }^{0} G_{\mathrm{Nd}}^{(\alpha \mathrm{Nd})}-0.6667{ }^{0} G_{\mathrm{Cu}}^{(\gamma \mathrm{Cu})}=-20250.0-1.3786 T$ & \\
\hline & $\alpha \mathrm{NdCu}$ & ${ }^{0} G_{\mathrm{Cu} u \mathrm{Nd}}^{\alpha \mathrm{NdCu}}-0.5{ }^{0} G_{\mathrm{Nd}}^{(\alpha \mathrm{Nd})}-0.5{ }^{0} G_{\mathrm{Cu}}^{(\gamma \mathrm{Cu})}=-18280.0-0.2176 T$ & \\
\hline & $\beta \mathrm{NdCu}$ & ${ }^{0} G_{\mathrm{Cu}: \mathrm{Nd}}^{\beta \mathrm{NdCu}}-0.5{ }^{0} G_{\mathrm{Nd}}^{(\alpha \mathrm{Nd})}-0.5{ }^{0} G_{\mathrm{Cu}}^{(\gamma \mathrm{Cu})}=-16592.3-2.4898 \mathrm{~T}$ & \\
\hline \multirow{8}{*}{$\mathrm{Fe}-\mathrm{Cu}$} & \multirow{4}{*}{$(\mathrm{L})$} & ${ }^{0} L_{\mathrm{Cu}, \mathrm{Fe}}^{(\mathrm{L})}=73316.72-142.79 T+15.82 T \ln T$ & \multirow{8}{*}{ 57) } \\
\hline & & ${ }^{1} L_{\mathrm{Cu}, \mathrm{Fe}}^{(\mathrm{L})}=9100.15-5.94 T$ & \\
\hline & & ${ }^{2} L_{\mathrm{Cu}, \mathrm{Fe}}^{(\mathrm{L})}=2428.96$ & \\
\hline & & ${ }^{3} L_{\mathrm{Cu}, \mathrm{Fe}}^{(\mathrm{L})}=-233.62$ & \\
\hline & $(\alpha \mathrm{Fe})$ & ${ }^{0} L_{\mathrm{Cu}, \mathrm{Fe}}^{(\alpha \mathrm{Fe})}=40146.22-4.91 T$ & \\
\hline & \multirow{3}{*}{$(\gamma \mathrm{Fe}, \gamma \mathrm{Cu})$} & ${ }^{0} L_{\mathrm{Cu}, \mathrm{Fe}}^{(\gamma \mathrm{Fe}, \mathrm{Cu}}=48885.74-11.51 T$ & \\
\hline & & ${ }^{1} L_{\mathrm{Cu}, \mathrm{Fe}}^{(\gamma \mathrm{Fe} C}=12687.16-8.01 T$ & \\
\hline & & ${ }^{2} L_{\mathrm{Cu}, \mathrm{Fe}}^{(\mathrm{rFe} \mathrm{Cu})}=4054.11$ & \\
\hline \multirow{6}{*}{$\mathrm{Nd}-\mathrm{Fe}-\mathrm{Cu}$} & \multirow{3}{*}{ (L) } & ${ }^{0} L_{\mathrm{Cu}, \mathrm{Fe}, \mathrm{Nd}}^{\mathrm{L})}=19048.34-144.82 T$ & \multirow{6}{*}{ Present work } \\
\hline & & ${ }^{1} L_{\mathrm{Cu}, \mathrm{Fe}, \mathrm{Nd}}^{(\mathrm{L})}=-217949.8-25.4 T$ & \\
\hline & & ${ }^{2} L_{\mathrm{Cu}, \mathrm{Fe}, \mathrm{Nd}}^{(\mathrm{L})}=-140014.9+136.31 T$ & \\
\hline & $\delta\left(\mathrm{Fe}_{13} \mathrm{Nd}_{6} \mathrm{Cu}\right)$ & ${ }^{0} G_{\mathrm{Fe}: \mathrm{Nd}: \mathrm{Cu}}^{\mathrm{Fe}_{\mathrm{e}} \mathrm{Nd} \mathrm{Cu}^{-}}-0.65{ }^{0} G_{\mathrm{Fe}}^{(\alpha \mathrm{Fe})}-0.30{ }^{\circ} G_{\mathrm{Nd}}^{(\alpha \mathrm{Nd})}-0.05{ }^{\circ} G_{\mathrm{Cu}}^{(\gamma \mathrm{Cu})}=98-101.1 T+13.9765 T \ln T$ & \\
\hline & $\alpha \mathrm{Nd}(\mathrm{Fe}, \mathrm{Cu})$ & ${ }^{0} L_{\mathrm{Cu}, \mathrm{Fe}: \mathrm{Nd} d \mathrm{Cu})}^{\alpha \mathrm{Nd}}=-13930+9.91 T$ & \\
\hline & $\beta \mathrm{Nd}(\mathrm{Fe}, \mathrm{Cu})$ & ${ }^{0} L_{\mathrm{Cu}, \mathrm{Fe}: \mathrm{Nd} d}^{\beta \mathrm{Ndd})}=-13930+9.91 T$ & \\
\hline
\end{tabular}

$ら^{62)}$, Lysenko ${ }^{63)}$, Wang $^{64)}$, Wang $~^{65)}$, Hussain $~^{66)}$ によ り行われている。本研究では相境界, 化合物の生成エネル ギー, 融解に伴う熱量変化などの実験值をよく再現し, 他の 合金系と整合する熱力学モデルを採用しているWang ら ${ }^{65)}$ の 熱力学パラメー夕を採用した. $\mathrm{Nd}-\mathrm{Cu} 2$ 元系の熱力学パラ メータをTable 3 に示した. これを用いて計算した 2 元系状 態図を相境界の実験值 ${ }^{16,55)}$ とともに Fig. 7 に示した.

\subsection{3 $\mathrm{Fe}-\mathrm{Cu} 2$ 元系}

$\mathrm{Fe}-\mathrm{Cu} 2$ 元系は液相 $(\mathrm{L}),(\alpha \mathrm{Fe}),(\gamma \mathrm{Fe}),(\delta \mathrm{Fe}),(\gamma \mathrm{Cu})$ の各一 次固溶体から構成されている. 液相線, 固相線, 固溶度など の相境界は多くの研究者により様々な実験手法で調べられ ている ${ }^{67-82)}$ 。また高温熱量計による液相の混合エンタル ピー67,74,83-92), 液相, $(\gamma \mathrm{Fe})$ 固溶体中および $(\gamma \mathrm{Cu})$ 固溶体中の
活量 ${ }^{91-99)}$ などの熱力学的性質についても報告されている.さ らに液相の混合エンタルピーの実験值から推測された液相の 2 相分離などの準安定平衡が，急冷した合金の磁化率測定 ${ }^{100)}$, 高純度急冷合金の EPMA 測定 ${ }^{101)}$ ，急冷合金の DTA 測定 ${ }^{102)}$ により調べられている.

この 2 元系についての多くの熱力学的解析が行われてい る $^{67,74,79,81,103-105)}$. これらの解析のうちで Turchanin ら ${ }^{67)}$ は準 安定平衡を含めた熱力学的解析を行っており，相境界も実験 と良い一致を示しているため, 本系では Turchanin らの解析 結果を採用した. $\mathrm{Fe}-\mathrm{Cu} 2$ 元系の熱力学パラメータを Table 3 に示した。これを用いて計算した 2 元系状態図を相境界の実 験值 ${ }^{68-74,76-80,82)}$ とともに Fig. 8 に示した. 


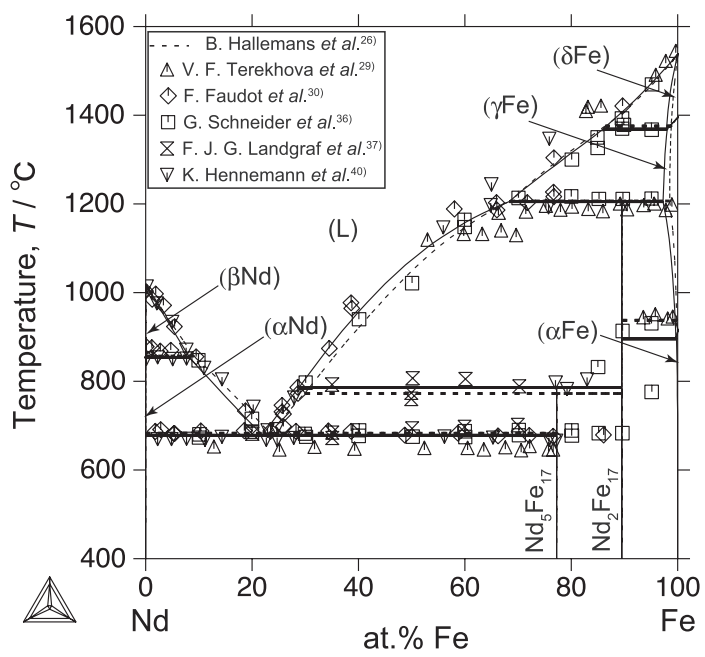

Fig. 2 Calculated Nd-Fe binary phase diagram compared with some experimental data. ${ }^{29,30,36,37,40)}$ The dotted lines represent the calculated phase boundaries by Hallemans et $a .^{26)}$

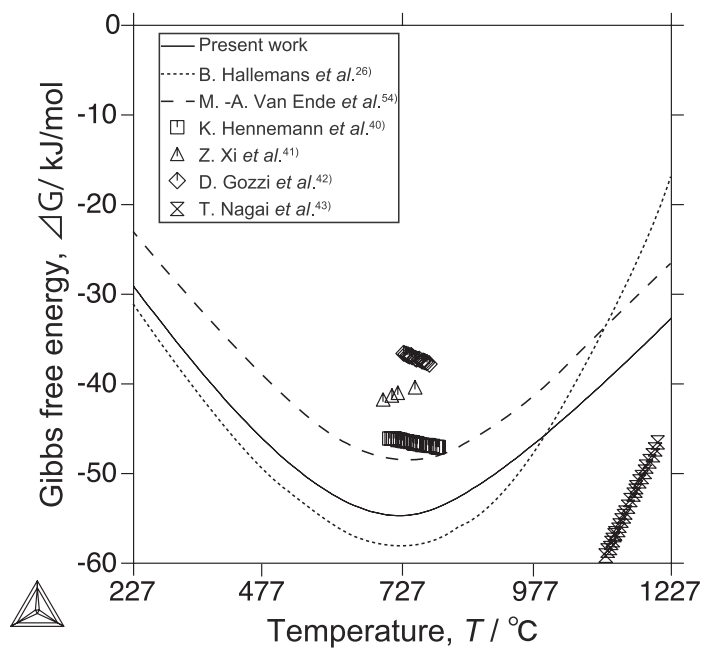

Fig. 3 Calculated Gibbs free energies of $\mathrm{Nd}_{2} \mathrm{Fe}_{17}$ compared with some experimental ${ }^{40-43)}$ and calculated data. ${ }^{26,54)}$ The unit of the free energy is expressed in 1 mole of the formula unit of each compound.

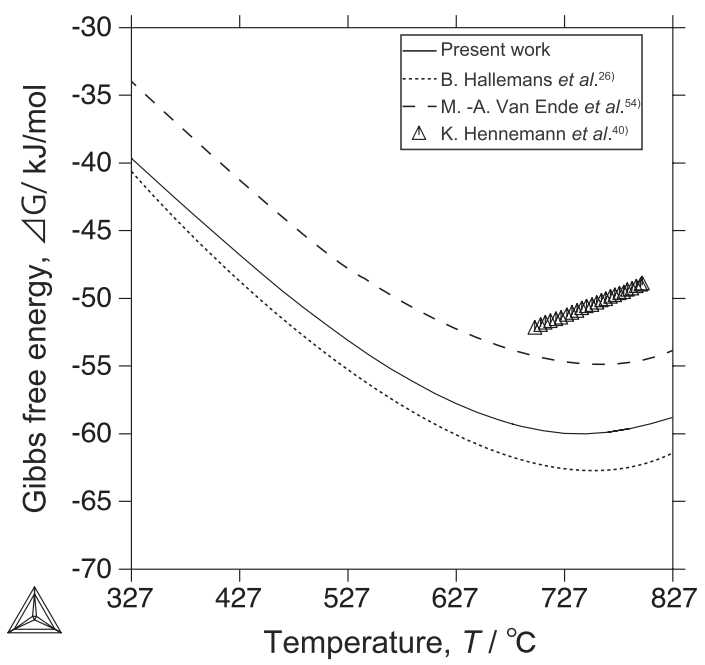

Fig. 4 Calculated Gibbs free energies of $\mathrm{Nd}_{5} \mathrm{Fe}_{17}$ compared with some experimental ${ }^{40)}$ and calculated data. ${ }^{26,54)}$ The unit of the free energy is expressed in 1 mole of the formula unit of compound.

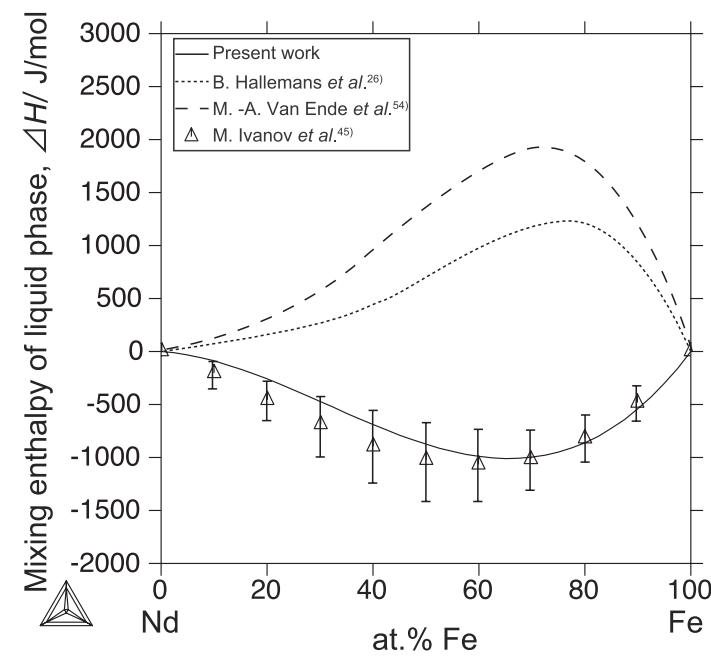

Fig. 5 Calculated mixing enthalpy of liquid phase at $1556^{\circ} \mathrm{C}$ $(1829 \mathrm{~K})$ compared with some experimental ${ }^{45)}$ and calculated $\operatorname{data}^{26,54)}$.

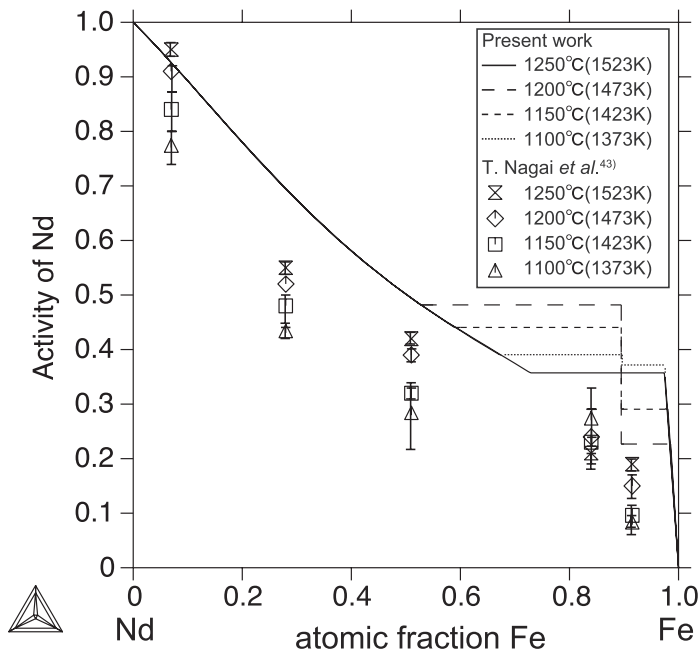

Fig. 6 Calculated activity of $\mathrm{Nd}$ compared with some experimental data ${ }^{43)}$.

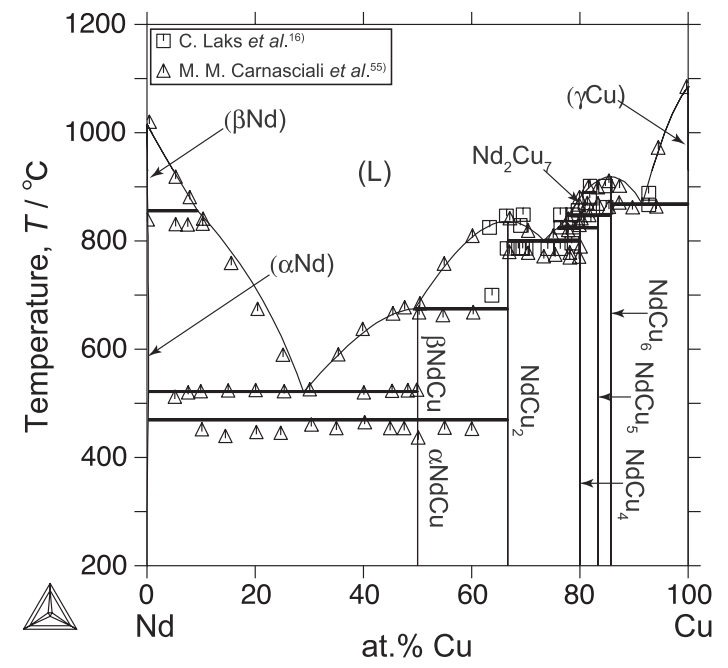

Fig. 7 Calculated $\mathrm{Nd}-\mathrm{Cu}$ binary phase diagram compared with some experimental data ${ }^{16,45)}$. 


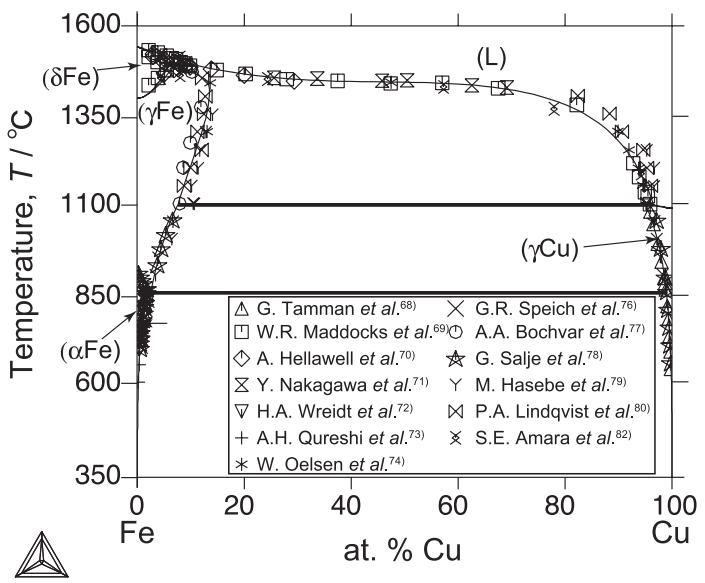

Fig. 8 Calculated $\mathrm{Fe}-\mathrm{Cu}$ binary phase diagram compared with some experimental data ${ }^{58-64,66-70,72)}$.

\subsection{4 $\mathrm{Nd}-\mathrm{Fe}-\mathrm{Cu} 3$ 元系}

$\mathrm{Nd}-\mathrm{Fe}-\mathrm{Cu} 3$ 元系の相平衡に関する報告は少ない.Jinqui, Jianxuan ${ }^{106)}$ は室温に打ける $\mathrm{Fe}$ と平衡する 2 元系化合物の平 衡を調べた。この中で $\mathrm{NdFe}_{2}$ のラーベス相の生成を報告して いるが，これは高温，高圧の条件だけで生成することが知ら れている ${ }^{31}$. また $\delta\left(\mathrm{Nd}_{6} \mathrm{Fe}_{13} \mathrm{Cu}\right)$ とよばれる 3 元化合物は観察 されていないが，これは組成分析を行わなかったためである と考えられる。ささらに高圧条件下での化合物については,

Tsvyashchenko, Fomicheva ${ }^{107)}$ が $7.7 \mathrm{GPa}, 1400-1450^{\circ} \mathrm{C}$ の条 件下で熱処理することで $\mathrm{C} 14$ 型の構造をもつ $\mathrm{NdFeCu}$ を確認 している. Grieb ${ }^{108)}$ は 52 at.\% Nd の等濃度断面に打ける相平 衡を報告した. Allibert ${ }^{109)}$ は $\mathrm{Nd}-\mathrm{Fe}-\mathrm{B}$ 系焼結磁石への $\mathrm{Cu}$ の 添加は粒界における $\mathrm{Nd}(\mathrm{Fe}, \mathrm{Cu})$ 相の形成を促進することを述 べている. Knoch, Harris ${ }^{110)}$ は $\mathrm{Cu}$ を添加した $\mathrm{Nd}-\mathrm{Fe}-\mathrm{B}$ 系焼 結磁石において, $\mathrm{Nd}_{30} \mathrm{Fe}_{65} \mathrm{Cu}_{5}$ の組成点における $650^{\circ} \mathrm{C}$ 近傍で の偏晶反応により 3 元化合物が生成するとしているが，これ は tetragonal 構造を持ち, $\mathrm{Nd}-\mathrm{Fe}-\mathrm{Al}, \mathrm{Nd}-\mathrm{Fe}-\mathrm{Ga}$ 系などで観 察されてきた $\delta$ 相と同じものと考えられている ${ }^{4)}$.

この 3 元系について Müller ら ${ }^{4)}$ の報告が最も包括的であ る. 彼らは相平衡解析にはDTA, 走査型電子顕微鏡 (Scanning Electron Microscope. 以下 SEM とする)，エネルギー分散型 X 線分析装置 (Energy Dispersive X-ray detector. 以下 EDX)を 用い，液相面解析には微細組織観察およびDTAを用いて，凝 固特性と固相状態を調查した。 その結果, 化学量論組成とし て $\mathrm{Nd}_{6} \mathrm{Fe}_{13} \mathrm{Cu}$ を持つ 3 元化合物 $\delta$ が確認された.この化合物 は固溶領域を持たず， $610^{\circ} \mathrm{C}$ で液相と $\mathrm{Nd}_{2} \mathrm{Fe}_{17}$ から包晶反応に

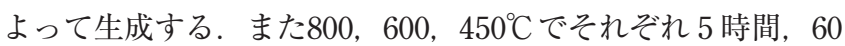

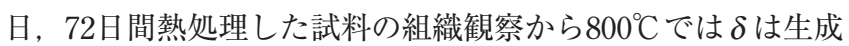
しないが， $600^{\circ} \mathrm{C} て ゙ は$ 生成していることがわかった，さらに 10 at. \% $\mathrm{Cu} ， 30$ at.\% Cu，33 at.\% Nd の組成に扔ける縦断面状態 図では，いずれの断面に扔いても $\delta$ 相の生成が確認された。

本研究では, $\mathrm{Nd}-\mathrm{Fe}-\mathrm{Cu} 3$ 元系に押いて 3 元化合物 $\delta$ の工 ンタルピーを第一原理計算により評価した。また $\alpha \mathrm{Nd}(\mathrm{Fe}$, $\mathrm{Cu}$ ) 相については2.1. 節, 2.2. 節で示した手法を用い生成自由 エネルギーを評価し，その值を含めた熱力学解析を行った。 $\alpha \mathrm{Nd}(\mathrm{Fe}, \mathrm{Cu})$ 相からの同素変態により生成する $\beta \mathrm{Nd}(\mathrm{Fe}, \mathrm{Cu})$ 相についても Fe の置換が報告されている4 が, 結晶構造が不

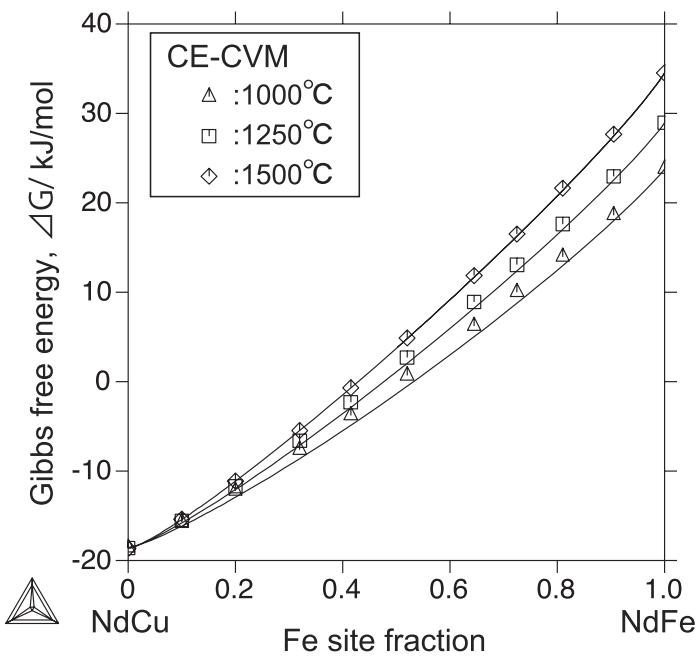

Fig. 9 Calculated Gibbs free energies of $\alpha \mathrm{Nd}(\mathrm{Fe}, \mathrm{Cu})$ using $\mathrm{CE}-\mathrm{CVM}$

明であるため，第一原理計算から熱力学物性値を評価するこ とが困難であった，そのため，本研究では $\beta \mathrm{Nd}(\mathrm{Fe}, \mathrm{Cu})$ 相中 の $\mathrm{Fe}$ と $\mathrm{Cu}$ の置換による相互作用を考慮し, 準安定 $\beta \mathrm{NdFe}$ 相については $\alpha \mathrm{Nd}(\mathrm{Fe}, \mathrm{Cu})$ 相と同じ熱力学パラメータを持つ と仮定した. $\alpha \mathrm{Nd}(\mathrm{Fe}, \mathrm{Cu})$ 相の生成自由エネルギーの計算值 と, 熱力学的解析の結果を Fig. 9 に示した. $\delta$ 相の磁性につ いては, Knoch ら ${ }^{18)} に よ り$ 解析が行われ，副格子の磁気モー メントの打ち消し合いが不十分なことにより磁化は小さく なっていると報告されているため, 本研究では $\mathrm{Fe}$ と $\mathrm{Nd}$ のス ピンの向きを互いに逆方向に設定し，フェリ磁性体として計 算した。皇の結果，生成エンタルピーは $\mathrm{Nd}_{6} \mathrm{Fe}_{13} \mathrm{Cu} 1$ モルあ

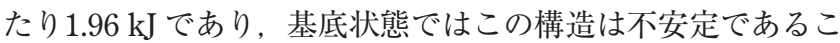
とがわかったそそこでこの結果を用いて，CALPHAD 法に よって温度依存項の解析を行った．溶体の相互作用パラメー 夕の解析には，Müllerらによって報告されている等温断面状 態図および縦断面状態図の液相の相境界デー夕を用いた。こ れらの解析結果を用いた計算結果と Müllerらの実験結果のう ち代表的な結果について Fig. 10，11 に扔いて計算状態図と比 較した．Fig. 10 では $450^{\circ} \mathrm{C} に お け る$ 等温状態図について (a) 実 験状態図 ${ }^{4)}$ と(b) 計算状態図，Fig. 11 では30 at.\% Cu の組成 における縦断面状態図について (a) 実験状態図 ${ }^{4)}$ と(b) 計算状 態図を比較した，縦断面状態図の計算結果から液相は Fe-rich 側で 2 相分離領域を有することがわかった。一方 Müller ら ${ }^{4)}$ は直接高温域の実験は行っていないが, $\mathrm{Nd}_{10} \mathrm{Fe}_{45} \mathrm{Cu}_{45}$ の組成 をもつ DTA 用試料の組織観察に打いて, Fe-rich の凝固組織 と $\mathrm{Cu}$-rich の凝固組織を確認したことから, この系の液相は 2 相分離傾向を有しているとし， 30 at.\% Cu の組成において Fig. 11(a) 中拡大図で示したような液相の 2 相分離の存在を予 測している.

液相面投影図の計算結果を Fig. 12 に示した。計算結果よ り, $\mathrm{Nd}_{10} \mathrm{Fe}_{45} \mathrm{Cu}_{45}$ の組成をもつ液相は 2 相分離することが示 されており，実験から予測された 2 相分離領域と一致するこ とが分かる。 また液相は Nd-rich 領域に扔いて 3 元共晶反応 $\mathrm{E}_{1}:(\mathrm{L}) \Leftrightarrow \beta \mathrm{NdCu}+(\alpha \mathrm{Nd})+\delta$ を生じ, $\mathrm{E}_{1}: 508.6^{\circ} \mathrm{C}$ と極めて低 温まで安定であることが分かった。 

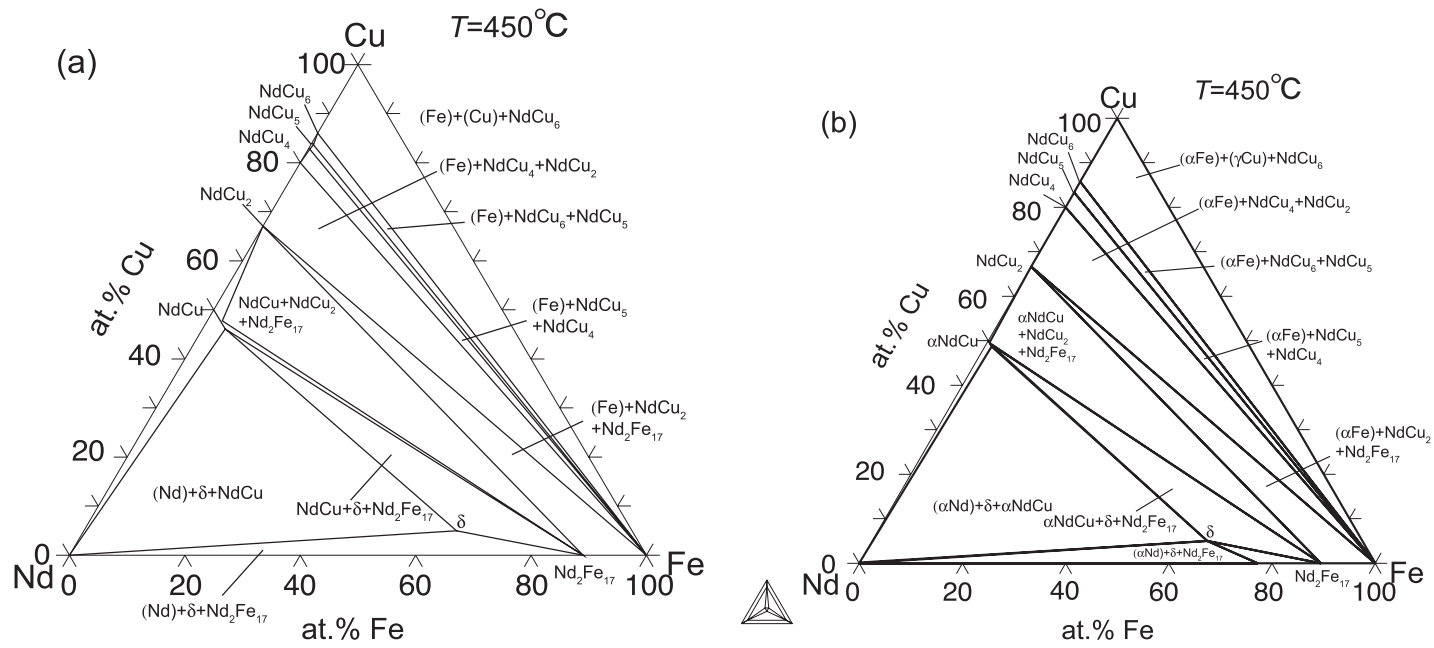

Fig. 10 Comparison of the isothermal section diagrams of the $\mathrm{Nd}-\mathrm{Fe}-\mathrm{Cu}$ ternary system at $T=450^{\circ} \mathrm{C}$ between (a) experiment and (b) calculation. The phase notation given in the experimental diagram is quoted from the original literature ${ }^{4)}$.
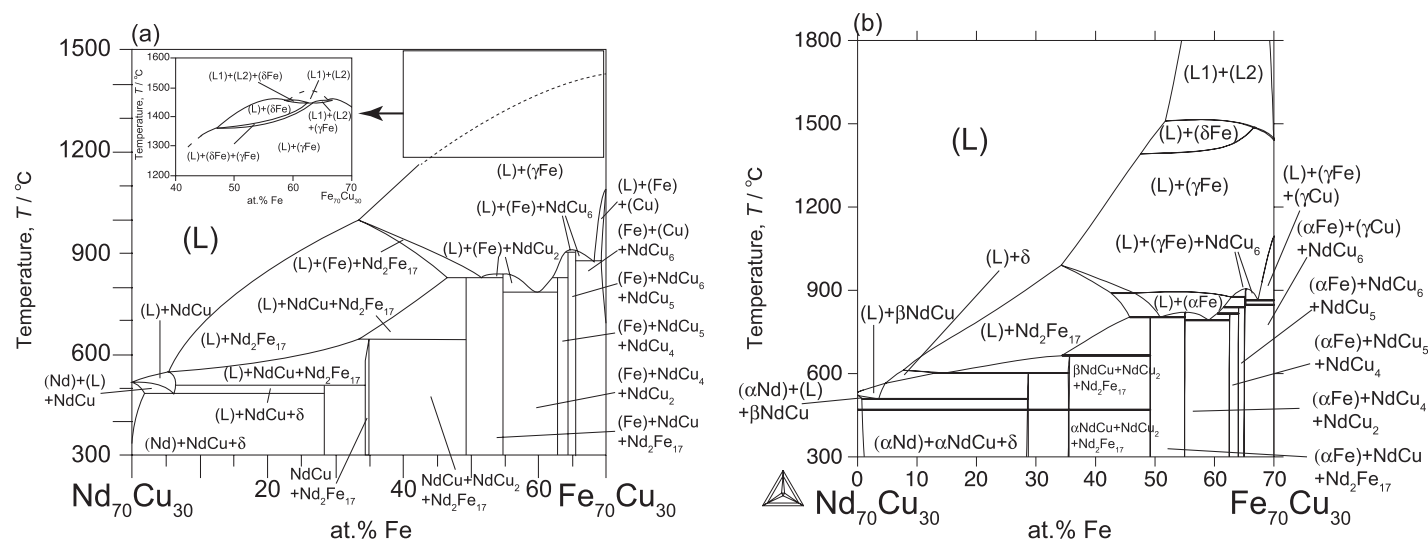

Fig. 11 Comparison of the isopleth section at 30 at.\% $\mathrm{Cu}$ of the $\mathrm{Nd}-\mathrm{Fe}-\mathrm{Cu}$ ternary system between (a) experiment and (b) calculation. The phase notation given in the experimental diagram is quoted from the original literature ${ }^{4)}$.

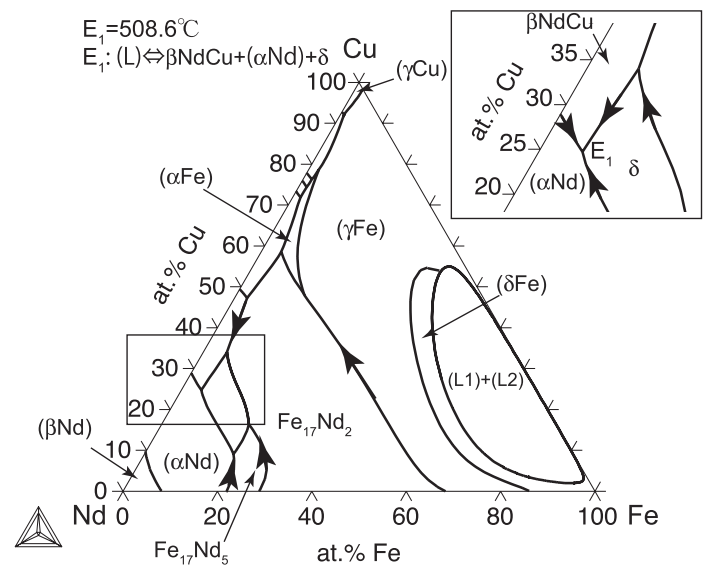

Fig. 12 Calculated liquidus projection of the $\mathrm{Nd}-\mathrm{Fe}-\mathrm{Cu}$ ternary system. Two-phase separation occurs in the $\mathrm{Fe}-\mathrm{Cu}$-rich side.

\section{2 液相の凝固過程に及ぼす $\mathrm{Cu}$ 添加の影響}

$\mathrm{Nd}-\mathrm{Fe}-\mathrm{B}$ 系への $\mathrm{Cu}$ の添加によって， $\mathrm{Al}, \mathrm{Ga}$ などとともに 磁性結晶粒同士の相互作用を分断する効果があることが知ら れている ${ }^{4)}$. Kianvash ら ${ }^{111)}$ は $\mathrm{Cu}$ を添加した $\mathrm{Nd}-\mathrm{Fe}-\mathrm{B}$ 合金 を焼結，熱処理すると保磁力が向上するとしている。これは
熱処理によって $\mathrm{Nd}-\mathrm{Cu}-\mathrm{Fe}$ 相が Nd-rich 相を消費して粒界に 生成するためである。一方, HDDR 法は焼結法では得られな い微細な結晶粒から構成される異方性磁石が作成できるため に, $\mathrm{Nd}-\mathrm{Fe}-\mathrm{B}$ 系合金へも適用されている方法である。この際 脱水素 - 再融合 $(\mathrm{DR})$ 過程において, $\mathrm{Nd}_{2} \mathrm{Fe}_{14} \mathrm{~B}$ 相を熱処理す ると，粒界三重点に形成された $\mathrm{Nd}-$ rich 相 $\left(\mathrm{Nd}, \mathrm{NdCu}, \mathrm{NdO}_{\mathrm{x}}\right.$ など)の $\mathrm{Nd}, \mathrm{NdCu}$ が溶融し，これが粒界に浸透することに よって保磁力の発現に大きく寄与することが明らかになっ た ${ }^{112,113)}$.さらにこの方法を応用して，HDDRにより作製さ れた磁性粉末に超急冷法による $\mathrm{Nd}-\mathrm{Cu}$ 系共晶合金を混合し て熱処理することで，保磁力が大幅に向上することも示され た ${ }^{2)}$. この報告では, $600^{\circ} \mathrm{C}, 1$ 時間の熱処理を行うと, $\mathrm{Nd}_{2} \mathrm{Fe}_{14} \mathrm{~B}$ 相の結晶粒界に $\mathrm{Cu}$ を含む結晶粒界が観察されてい る. また熱処理後の粒界の平均組成は, 三次元アトムプロー ブより $\mathrm{Nd}_{6} \mathrm{Fe}_{13.2} \mathrm{Cu}_{0.2} \mathrm{~B}_{0.62}$ であると報告されている ${ }^{114)}$.

本研究で計算した $\mathrm{Nd}-\mathrm{Fe}-\mathrm{Cu} 3$ 元系の液相線投影図 (Fig. 12)によれば, $\mathrm{Nd}-\mathrm{Cu} 2$ 元系の共晶点近傍に 3 元共晶点が存 在する.このことから, $\mathrm{Nd}-\mathrm{Cu} 2$ 元系の共晶点近傍の組成を 持つ析出物が融解し $\mathrm{Nd}$ と Fe を含む粒界に浸透した場合, $\mathrm{Fe}$ をわずか 5 at. \%程度含む液相として凝固することがわかる. このように液相の組成を $\mathrm{Nd}-\mathrm{Cu}$ 側にした場合に液相へ Fe が 
ほとんど溶け込まない理由は, 熱力学的には液相中での Fe と $\mathrm{Cu}$ 原子の間に斥力が働くことに起源を求めることができる. また凝固組織には組成の離れた $\delta$ が含まれているが，これが 三次元アトムプローブにより同定された粒界部の組成ときわ めて近いことも興味深い事実である．融点直上の液相合金は しばしば凝固により晶出する初晶に近い構造や組成を持つこ とが知られているが，ここで見られた実験結果と計算結果の 符合はこのことと関連を持つ可能性があるので，さらに今後 検討していく必要がある。

\section{4. 結言}

本研究ではネオジム磁石の保磁力を向上させる元素として 重要な $\mathrm{Cu}$ の添加効果を明らかにする目的で，その基本系で ある $\mathrm{Nd}-\mathrm{Fe}-\mathrm{Cu} 3$ 元系状態図の熱力学的解析を行い, 以下の 結論を得た。

(1) $\mathrm{Nd}-\mathrm{Fe}-\mathrm{Cu} 3$ 元系の液相面投影図を計算した。この結 果, この系では液相は $\mathrm{Fe}$ と $(\mathrm{Nd}, \mathrm{Cu})$-rich 側へ 2 相分離する ことがわかった。これは組織観察から予測された 2 相分離傾 向を再現していた。さらに液相面投影図から，この系は $(\mathrm{Nd}$, $\mathrm{Cu})$-rich 側に極めて低温の 3 元共晶点を持つことを確認した.

(2) 計算より 3 元共晶反応は $(\mathrm{Nd}, \mathrm{Cu})$-rich 側の領域にお いて $(\mathrm{L}) \Leftrightarrow \beta \mathrm{NdCu}+(\alpha \mathrm{Nd})+\delta$ であることがわかった。 これ は $\mathrm{Nd}-\mathrm{Cu}$ 溶融合金に $\mathrm{Fe}$ を添加した場合，液相中の平均 $\mathrm{Fe}$ 濃度は低いが， 3 元共晶反応に関与する $\delta$ 相に起因し Fe-rich の領域が出現することを示唆している.

本研究の一部は (独) 科学技術振興機構・戦略的創造研究推 進事業 (CREST)「元素戦略を基軸とする物質・材料の革新的 機能の創出」(玉尾皓平研究統括)研究領域による研究助成を受 けて遂行されました。

文 献

1) M. Sagawa, S. Fujimura, N. Togawa, H. Yamamoto and Y. Matuura: J. Appl. Phys. 55 (1984) 2083-2087.

2) H. Sepehri-Amin, T. Ohkubo, T. Nishiuchi, S. Hirosawa and K. Hono: Scr. Mater. 63(2010) 1124-1127.

3) T. Takashita and R. Nakayama: Proc. 10th Int. Workshop on Rare-Earth Magnets and their Applications, Kyoto, Vol. 1(1989) p. 551.

4) C. Müller, B. Reinsch and G. Petzow: Z. Metallkd. 83(1992) 845-852.

5) R. Kikuchi: Phys. Rev. 81(1951) 988-1003

6) D. de Fontaine: Solid State Physics, Vol. 34 (Academic Press, New York, 1979) pp. 73-274.

7) M. Uemitsu, M. Enoki, S. Iikubo and H. Ohtani: J. Japan Inst. Met. Mater. 78 (2014) 327-336.

8) V. L. Moruzzi, J. F. Janak and K. Schwarz: Phys. Rev. B 37 (1988) $790-799$.

9) X.-G. Lu, M. Selleby and B. Sundman: Acta Mater. 53(2005) 2259-2272

10) X.-G. Lu, M. Selleby and B. Sundman: Acta Mater. 55(2007) 1215-1226.

11) J. S. Dugdale and D. K. C. MacDonald: Phys. Rev. 89(1953) 832-834.

12) F. Birch: Phys. Rev. 71(1947) 809-824.

13) T. Kajitani, Y. Morii, S. Funahashi, T. Iriyama, K. Kobayashi, H. Kato, Y. Nakagawa and K. Hiraya: J. Appl. Phys. 73(1993) 6032-6034

14) M. Moreau, L. Paccard, J. P. Nozieres, F. P. Missell, G. Schneider and V. Villas-Boas: J. Less-Common Met. 163(1990) 245-251.
15) M. L. Vrtis, J. D. Jorgensen and D. G. Hinks: J. Solid State Chem. 84(1990) 93-101.

16) C. Laks, J. Pelleg and L. Zevin: J. Less-Common Met. 102(1984) 23-28.

17) E. Gratz, M. Loewenhaupt, M. Divis, W. Steiner, E. Bauer, N. Pillmayr, H. Muller, H. Nowotny and B. Frick: J. Phys.: Con dens. Matter 3(1991) 9297-9318.

18) K. G. Knoch, A. Le Calvez, Q. Qi, A. Leithe-Jasper and J. M. D. Coey: J. Appl. Phys. 73 (1993) 5878-5880.

19) A. T. Dinsdale: Calphad 15(1991) 319-427.

20) O. Redlich and A. T. Kister: Ind. Eng. Chem. 40(1948) 345348.

21) M. Hillert: Calphad 4(1980) 1-12.

22) M. Hillert and L.-I. Staffansson: Acta Chem. Scand. 24(1970) 3618-3626.

23) G. Inden: Proc. CALPHAD V, (Dusseldorf, 1976).

24) M. Hillert and M. Jarl: CALPHAD 2(1978) 227-238.

25) W. Zhang, G. Liu and K. Han: Phase Diagrams of Binary Iron Alloys, (ASM International, Materials Park, Ohio, 1993) pp. 253-255.

26) B. Hallemans, P. Wollants and J. R. Roos: J. Phase Equilibria 16(1995) 137-149.

27) H. Okamoto: J. Phase Equilibria 18(1997) 106.

28) R. Marazza, P. Riani and G. Cacciamani: Inorg. Chim. Acta 36 (2008) $3800-3806$

29) V. F. Terekhova, E. V. Maslova and Y. M. Savitsliy: Russ. Metall. 3(1965) 50-52.

30) F. Faudot, M. Harmelin and J. Bigot: Scr. Metall. 23(1989) 795798.

31) J. F. Cannon, D. L. Robertson and H. T. Hall: Mat. Res. Bull. 7 (1972) 5-12.

32) H. H. Stadelmaier, N. A. El-Masry, N. C. Liu and S. F. Cheng: Materials Lett. 2(1984) 411-415.

33) K. H. J Buschow, D. B. De Mooij and H. M. Van Noort: Phillips J. Res. 40 (1985) 227.

34) Y. Matsuura, S. Hirosawa, H. Yamamoto, S. Fujimura, M. Sagawa and K. Osamura: Jpn. J. Appl. Phys. 24(1985) L635-637.

35) G. Che, J. Liang and X. Wang: Sci. Sin. (Ser. A) 29(1986) 11721185

36) G. Schneider, E. T.-Th Hening, G. Petzow and H. H. Stadelmaier: Z. Metallkde 78(1987) 694-696.

37) F. J. G. Landgraf, G. S. Schneider, V. Villas-Boas and F. P. Missell: J. Less-Common Met. 163(1990) 209-218.

38) G. Schneider, E. T.-Th Hening, G. Petzow and H. H. Stadelmaier: (Proc. 5th Int. Symp. on Magnetic Anisotropy and Coercivity in Rare Earth-Transition Metal Alloys, Bad Soden, 1987) pp. $347-362$.

39) H. B. Ping, J. M. D. Coey, C. J. Cardin, E. J. Devlin and I. R. Harris: J. Less-Common Met. 144(1988) L29-L31.

40) K. Hennemann, H. L. Lukas and H. J. Schaller: Z. Metallk. 84 (1993) 668-674.

41) Z. Xi and C. Ji: Nonferr. Met. 41 (1989) 68-71.

42) D. Gozzi, M. Iervolino and A. Latini: J. Chem. Eng. Data 52 (2007) 2350-2358.

43) T. Nagai, S. Shirai and M. Maeda: Thermochim. Acta, 516(2011) 8-12.

44) S. V. Meschel, P. Nash, Q. N. Gao, J. C. Wang and Y. Du: J. Alloy Compd. 554(2013) 232-239.

45) M. Ivanov, V. Berezutski, N. Usenko and N. Kotova: Int. J. Mater. Res., 104(2013) 849-857.

46) Y. He, X. R. Chang, Z. Z. Tian, C. M. Hsiao, M. H. Wang, H B. Lu, Y. Y. Wang and N. Q. Liu; Scr. Metall. 19(1985) 79-82.

47) F. Zhang, L. Gu, L. Qu, W. Liu and Y. Yan: Acta Metall. Sin. 23 (1987) A503-A506.

48) L. Li and Z. Xing: Acta Metall. Sin. 29(1993) A136-A141.

49) B. P. Hu and J. M. D. Coey: J. Less-Common Met. 142 (1988) 295-300.

50) O. Isnard, S. Miraglia, J. L. Soubeyroux and D. Fruchart: Solid State Commun. 81(1992) 13-19.

51) W. B. Cui, W. Liu, X. G. Zhao, S. L. Chen, Q. Yao and Z. D. Zhang: J. Alloys Compd. 436(2007) 392-395.

52) J. P. Nozières and H. R. Rechenberg: Solid State Commun. 79 (1991) 21-24.

53) C. Lin, C. X. Liu, Y. X. Sun and Z. X. Liu: J. Phys.: Condens. Matter 9(1997) 9353-9360

54) M.-A. Van Ende and I.-H. Jung: J. Alloy Compd. 548(2013) 133-154

55) M. M. Carnasciali, G. A. Costa and E. A. Franceschi: J. LessCommon Met. 92(1983) 97-103

56) V. V. Etimov, L. A. Ryabtsev, E. V. Lysova and T. M. Frolova: 
Izv. Vyssh. Uchebn. Zaved., Tsvetn. Metall. 2(1988) 85-90.

57) H. Z. Gu and J. Q. Song: Acta Sci. Natur. Univ. Pekin. 26 (1990) 136-140.

58) G. J. Qi, K. Itagaki and A. Yazawa: Mater. Trans. JIM 30(1989) 273-282.

59) G. A. Costa, E. A. Feancheschi and A. Tawansi: J. Thermal Anal. 29 (1984) 665-671.

60) K. Fitzner and 0. J. Kleppa: Metall. Mater. Trans. 25A(1994) 1495-1500.

61) M. A. Turchanin, I. V. Nikolaenko and G. I. Batalin: Rasplavy 2(1988) $118-119$.

62) Y. Du and N. Clavaguera: Scr. Mater. 34(1996) 1609-1613.

63) V. A. Lysenko: Russ. J. Phys. Chem. 77 (2003) 1392-1396.

64) J. X. Wang: CALPHAD 16(1992) 87-92.

65) P. Wang, L. Zhou, Y. Du, H. Xu, S. Liu, L. Chen and Y. Ouyang: J. Alloy. Compd. 509(2011) 2679-2683.

66) A. Hussain, M.-A. Van Ende. J. Kim and I.-H. Jung: CALPHAD 41 (2013) 26-41.

67) M. A. Turchanin, P. G. Agraval and I. V. Nikolaenko: J. Phase Equilib. 24(2003) 307-319.

68) G. Tamman and W. Oelsen: Z. Anorg. Allgem. Chem. 186(1930) 257-288.

69) W. R. Maddocks and G. E. Claussen: Iron Steel Inst. Spec. Rep. 14(1936) $97-124$

70) A. Hellawell and W. Hume-Rothery: Philos. Trans. R. Soc. London 249A (968) (1957) 417-459.

71) Y. Nakagawa: Acta Metall. 6(11) (1958) 704-711.

72) H. A. Wreidt and L. S. Darken: Trans. Met. Soc. AIME 218 (1960) 30-36.

73) A. H. Qureshi: Z. Metallk. 52(1961) 799-813.

74) W. Oelsen, E. Schurmann and C. Florin: Arch. Eisenhuttenwesen 32(1961) 719-728.

75) E. P. Abrahamson and S. L. Lopata: Trans. Met. Soc. AIME 236 (1966) $76-87$.

76) G. R. Speich, J. A. Gula and R. M. Fisher: Diffusivity and Solubility Limit of Copper in Alpha and Gamma Iron," in Electron Microprob., ed. by T. D. McKinley, K. J. Heinrich and D. B. Witty, (John Wiley and Sons, New York, 1966) pp. 525-541.

77) A. A. Bochvar, A. S. Ekatova, E. V. Panchenko and Yu. F. Sidokhin: Dokl. Akad. Nauk SSSR 174(1967) 863-864.

78) G. Salje and M. Feller-Kniepmeier: Z. Metallk. 69(1978) 167169.

79) M. Hasebe and T. Nishizawa: CALPHAD 4(1980) 83-100.

80) P. A. Lindqvist and B. Uhrenius: CALPHAD 4(1980) 193-200.

81) L. H. Chen, T. S. Chin and M. P. Hung: J. Appl. Phys. 64(1988) 5962-5964.

82) S. E. Amara, A. Belhadj, R. Kesri and S. Samar-Thibault: Z. Metallk. 90 (1999) 116-123.

83) A. El Khasan, K. Abdel-Aziz, A. A. Vertman and A. N. Samarin: Izv. Akad. Nauk SSSR, Metally, 3(1966) 19-30.

84) F. Wooley and J. F. Elliot: Trans. Met. Soc. AIME 239(1967) 1872-1883.

85) Y. Tozaki, Y. Iguchi, S. Ban-ya and T. Fuwa: Chem. Metall. Iron Steel, Proc. Int. Symp. Metall. Chem.-Appl. Ferrous Metall. 1971, (Iron Steel Inst., London, UK, 1973) pp. 130-132.

86) G. I. Batalin and V. S. Sudavtsova: Izv. Akad. Nauk SSSR. Metally
2(1980) 45-49.

87) M. G. Frohberg and G. Betz: Arch. Eisenhüttenwesen 51 (1980) 235-240.

88) N. Maruyama and S. Banya: J. Jpn. Inst. Metals 44(1980) 14221431.

89) M. A. Turchanin and S. V. Porokhnya: Rasplavy 1(1995) 9-13

90) I. V. Nikolaenko and M. A. Turchanin: Metall. Mater. Trans. 28B (1997) 1119-1130.

91) J. P. Morris and G. R. Zellers: J. Met. Trans. AIME 8(1956) 1086-1091.

92) U. V. Chowdary, J. A. Serkin and G. R. Beltoon: Met. Trans. B 6(1975) 399-403.

93) G. I. Batalin and V. S. Sudavtsova: Izv. Akad. Nauk SSSR. Metally 2(1980) 45-49.

94) L. Timberg, J. M. Toguri and T. Azakami: Metall. Trans. 12B (1981) $275-279$.

95) L. Sh. Tsemekhman, V. P. Mintsis, B. P. Burylev, V. D. Linev and V. I. Volkov: Izv. Vyssh. Uchebn. Zaved. Chern. Metallurg. 3(1985) 1-4.

96) Y. G. Park and D. R. Gaskell: Metall. Trans. 20B(1989) 127135.

97) D. Robinson and B. B. Argent: Met. Sci. 10(1976) 219-221.

98) M. Arita, M. Takanaka, K. S. Goto and M. Someno: Metall Trans. 12A (1981) 497-504.

99) J. C. Gachon, M. Notin, C. Cunat, J. Hertz, J. C. Parlebas, G. Moraitis, B. Stupfel and F. Gautier: Acta Metall. 28(1980) 489497.

100) Y. Nakagawa: Acta Metall. 6(1958) 704-711.

101) S. P. Elder, A. Munits and G. J. Abashian: Mater. Sci. Forum 50 (1989) 137-150.

102) G. Wilde, R. Willnecker, R. N. Singh and F. Sommer: Z. Metallkd. 88(1997) 804-809.

103) O. Kubaschewski, J. F. Smith and D. M. Bailey: Z. Metallkd. 68(1977) 495-499.

104) M. Hasebe and T. Nishizawa: Calphad 5(1981) 105-108.

105) Y. Y. Chuang, R. Schmid and Y. A. Chang: Metall. Trans. 15A (1984) 1921-1930.

106) L. Jinqui and Z. Jianxuan: J. Chin. Rear Earth Soc. 5(1987) 79-81.

107) A. V. Tsvyashchenko and L. N. Fomicheva: J. Less-Comm. Met. 105(1989) L1-L3.

108) B. Grieb: Dr. rer. nat. Thesis, Universität Stuttgart (1991).

109) C. H. Allibert: Concerted European Action on Magnets, ed. by I. V. Mitchell, J. M. D. Coey, D. Givord, I. R. Harris, R. Hanitsch, (Elsevier Applied Science, London and New York, 1989) pp. 358-368.

110) K. G. Knoch and I. R. Harris: Z. Metallk. 83(1992) 338-341.

111) A. Kianvash and I. R. Harris: J. Alloy. Compd. 178(1992) 325341.

112) T. Nishiuchi, S. Hirosawa, M. Nakamura, M. Kakimoto, T. Kawabayashi, H. Araki and Y. Shirai: IEEJ Trans. Electr. Electr. Eng. 3(2008) 390-393.

113) W. F. Li, T. Ohkubo, K. Hono, T. Nishiuchi and S. Hirosawa: Appl. Phys. Lett. 93(2008) 052505.

114) H. Sepehri-Amin, T. Ohkubo, T. Shima and K. Hono: Acta Mater. 60 (2012) 819-830. 